\title{
Bat guano minerals and mineralization processes in Chameau Cave, Eastern Morocco
}

\author{
Philippe Audra (1D ${ }^{1 *}$, Vasile Heresanu (D) ${ }^{2}$, Lionel Barriquand ${ }^{3}$, Mohamed El Kadiri \\ Boutchich $^{4}$, Stéphane Jaillet (iD ${ }^{3}$, Edwige Pons-Branchu (D) ${ }^{5}$, Pavel Bosák ${ }^{6}$, Hai Cheng (D) ${ }^{7}$, \\ R. Lawrence Edwards (1D ${ }^{8}$, and Michel Renda ${ }^{9}$
}

${ }^{1}$ Polytech'Lab EA 7498, Université Côte d'Azur, 930 route des Colles, 06903 Sophia-Antipolis, France

${ }^{2}$ Centre Interdisciplinaire de Nanoscience de Marseille (CINaM), CNRS - Aix Marseille University, Campus de Luminy, case 913,

13288 Marseille cedex 9, France

${ }^{3}$ Université Savoie-Mont-Blanc, EDYTEM, UMR 5204, Bât. "Pôle Montagne", 5 bd. de la mer Caspienne, 73376 Le Bourget-du-Lac cedex, France

${ }^{4}$ Zegzel Valley Foundation, 63300 Berkane, Morocco

${ }^{5}$ Laboratoire des Sciences du Climat et de l'Environnement / Institut Pierre Simon Laplace (LSCE/IPSL), CEA-CNRS-UVSQ, Université de Paris-Saclay, Orme des Merisiers, 91191 Gif-sur-Yvette, France

${ }^{6}$ Institute of Geology, Czech Academy of Sciences, v.v.i., Rozvojová 269, 16500 Prague 6, Czech Republic

${ }^{7}$ Institute of Global Environmental Change, Xi'an Jiaotong University, Xi'an 710054, China \& Key Laboratory of Karst Dynamics, MLR, Institute of Karst Geology, CAGS, Guilin 541004, China

${ }^{8}$ Department of Earth Sciences, University of Minnesota, 3 Morrill Hall 100 Church St. S.E. Minneapolis MN 55455, USA

${ }^{9}$ IFREEMIS, 571 chemin du Chalet Vert, 11400 Castelnaudary, France

Abstract: $\quad$ The decay of bat guano deposits in caves produces mineral accumulations, mainly phosphates and secondary sulfates. Chameau Cave, Eastern Morocco, is located in the semi-arid Bni Snassen Mountains. It is composed of semi-active and dry passages, and is featured by strong condensation-corrosion on the walls, presence of fluvial sediments, and old corroded flowstones. Due to forced and convective airflow, the cave is generally very dry, with some damp sites related to condensation. Samples collected on the surface of different passages and along two sediment profiles yielded minerals related to bat guano decay. On recent or fresh guano, precursor minerals correspond to sulfate (gypsum), phosphate-sulfate (ardealite) and phosphate (brushite). Phosphates (hydroxylapatite, fluorapatite) occur at the interface with host rock or carbonate speleothems. At the contact of phyllosilicates contained in allogenic fluvial deposits or shale partings, or with pyrite-rich sediments, various phosphates occur (Alrich strengite, Fe-rich variscite, phosphosiderite, leucophosphite, spheniscidite, crandallite, minyulite, variscite, and strengite), the latter two minerals being the stable end-members. Black seams of oxyhydroxides (goethite, hematite, birnessite) line the contact between carbonate host rock and weathered fluvial deposits. After "digestion" by acidic guano leachates, fluvial deposits only display the most resistant minerals (quartz, muscovite, K-feldspars, and Na-plagioclases) and weathering byproducts (kaolinite). We discuss the origin of a pure gypsum particle cone, possibly related to evaporation at the edge of a wet cupola and subsequent detachment of sulfate particles. Among environmental conditions, humidity is required for decay. In this dry cave, most of the damp originates from either permanent or seasonal condensation. Dust particle advection seems to be essential in providing compounds that are not present on fresh guano (quartz, clay minerals). Bat guano phosphatization has probably occurred since $>100$ ka. The Chameau Cave appears as an outstanding site for bat guano-related minerals $(n=12)$, including rare phosphates (spheniscidite and minyulite).

Keywords: "candy-floss" gypsum, sulfates, phosphates, cave dust, condensation/evaporation Received 11 January 2021; Revised 24 March 2021; Accepted 25 March 2021

Citation: $\quad$ Audra P., Heresanu V., Barriquand L., El Kadiri Boutchich M., Jaillet S., Pons-Branchu E., Bosák P., Cheng H., Edwards R.L. and Renda M., 2021. Bat guano minerals and mineralization processes in Chameau Cave, Eastern Morocco. International Journal of Speleology, 50 (1), 91-109. Tampa, FL (USA) ISSN 0392-6672 https://doi.org/10.5038/1827-806X.50.1.2374

\section{INTRODUCTION}

Cave minerals are secondary minerals that form in caves. Bat guano accumulations are probably sites of the largest variety of minerals in caves ( $\mathrm{n}>100$ ), including nitrates, sulfates, and phosphates, the latter account for the largest group ( $\mathrm{n}>60$ ) (Onac \& Forti, $2011 \mathrm{a}, \mathrm{b}$; Onac, 2019). They are the result of the interaction between decaying guano leachates and carbonate cave bedrock or cave sediments (Martini \& Kavalieris, 1978; Hill \& Forti, 1997). The very soluble nitrates and sulfates are generally typical of extremely 
dry caves of arid areas, and are absent in wetter climatic zones; only gypsum is present in caves located outside of arid zones. In guano surroundings, the very acid leachates are responsible for the considerable corrosion of bedrock resulting in neutralization of the solutions and precipitation of phosphates, mainly of the apatite group. Cave sediments, especially when of allogenic origin, provide extended sources of various minerals that interact with acidic guano leachates, resulting in conditions favorable to a large mineral diversification (Onac et al., 2002; Audra et al., 2016). Among environmental conditions, the acidity/alkalinity and the moisture content are the most important control factors (Shahack-Gross et al., 2004; Giurgiu \& Tămaş, 2013; Puşcaş et al., 2014; and references therein).

Chameau Cave, located in the Bni Snassen Massif in Eastern Morocco, is a famous show cave, known for its beauty and for the source of an underground river at the origin of a unique green valley "island" in semi-arid mountains. As any major cave in such environment, it contains large guano accumulations left from past bat colonies, which are especially wellpreserved in the less accessible passages. Preliminary investigations have revealed the cave's mineralogical potential, especially for phosphates (Audra et al., 2018).

In this paper, we detail the bat guano minerals of Chameau Cave. In the first part, we review the environmental conditions of the Bni Snassen mountainous area, describe the Chameau Cave and its bat colonies, detail the sampling sites and profiles, and the methodological identification of minerals and their context. After an overview of microclimatic cave conditions, we present the mineralogical result. We finally discuss the different types of identified minerals, some rare accumulations such as candyfloss gypsum, the "digestion" of fluvial material into phosphates, and the environmental conditions that controlled their occurrence.

\section{STUDY SITE}

\section{Bni Snassen massif environment}

The studied area is located in Eastern Province, about $30 \mathrm{~km}$ to the Mediterranean Sea and the Algerian border. The Eastern Bni Snassen culminates at Jbel Foughal (1532 $\mathrm{m}$ asl.), the northeastern most part of the Middle Atlas chain. Its structure displays a dome of Jurassic limestones and marls, with a Paleozoic core built of schists, sandstones, basalts, and granite intrusions. Climate is typically dry Mediterranean, with a long dry season in summer. Average temperature in Berkane City (alt. $150 \mathrm{~m}$ ) is $18.2^{\circ} \mathrm{C}$, with daily extremes ranging from $6^{\circ} \mathrm{C}$ in winter up to $36^{\circ} \mathrm{C}$ in summer. Rainfall distribution shows an altitudinal and continental gradient, with $400 \mathrm{~mm}$ on the lower slopes exposed to the north, up to $600 \mathrm{~mm}$ on top with frequent snowfall in winter, but with less than $300 \mathrm{~mm}$ in the sheltered depression to the south (Fig. 1A). Therefore, the rivers, locally called "oued", have a temporary runoff, with large and generally dry riverbeds, having however huge episodic floods following intense storms. The oued Zegzel is the only perennial autochtonous river in the whole region $(\mathrm{Q}=40-1000 \mathrm{~L} / \mathrm{s})$, fed by springs pouring out from Chameau Cave (Ghazi, 1987). Over most of the area, the vegetation is mainly a Mediterranean scrub, with juniper (Juniperus oxycedrus) and oak bushes (Quercus rotundifolia and coccifera). An artificial forest of Alep pine (Pinus halepensis) covers the summit, however relic forests of Barbary thuja (Tetraclinis articulate) have been preserved. Finally, a dense gallery-forest fringes the Zegzel oued, made of bamboo (Arundo donax), willow (Salix pedicellata), rose laurel (Nerium oleander), and tamarix (Tamarix africana) (Fig. 1B) (Tarrier \& Delacre, 2007). Consequently, the Zegzel Valley appears as an evergreen area in comparison to the surrounding dry lands. Since 1953, it belongs to the list of the National Patrimonial Sites, and was more recently recorded as a "Site of biological and ecological interest" (SIBE) in the frame of the UNESCO Ramsar wet areas (AEFCS, 1996).

\section{Chameau Cave}

Cave description and exploration

Chameau Cave is located in Zegzel commune, Oujda province $\left(34.838251^{\circ} \mathrm{N}, 2.356086^{\circ} \mathrm{W}\right.$, alt. $460 \mathrm{~m})$. It is also known in Berber language as Tassera-kout, Moulaï Ahmed Caves (Joannis, 1915), and Ain Bourbah from the name of the spring. Chameau Cave is the main cave of the Bni Snassen Massif, with a length of $1.6 \mathrm{~km}$ and a relief of $57 \mathrm{~m}$ $(-11 /+46)$ (Fig. 2). It is a perennial spring partly at the origin of the permanent flow in the Zegzel Valley (Fig. 3A). The lower cave level is seasonally active $\left(Q_{\max }>1 \mathrm{~m}^{3} / \mathrm{s}\right)$, especially in winter, whereas several levels above are fossil. The large dimensions of the cave,

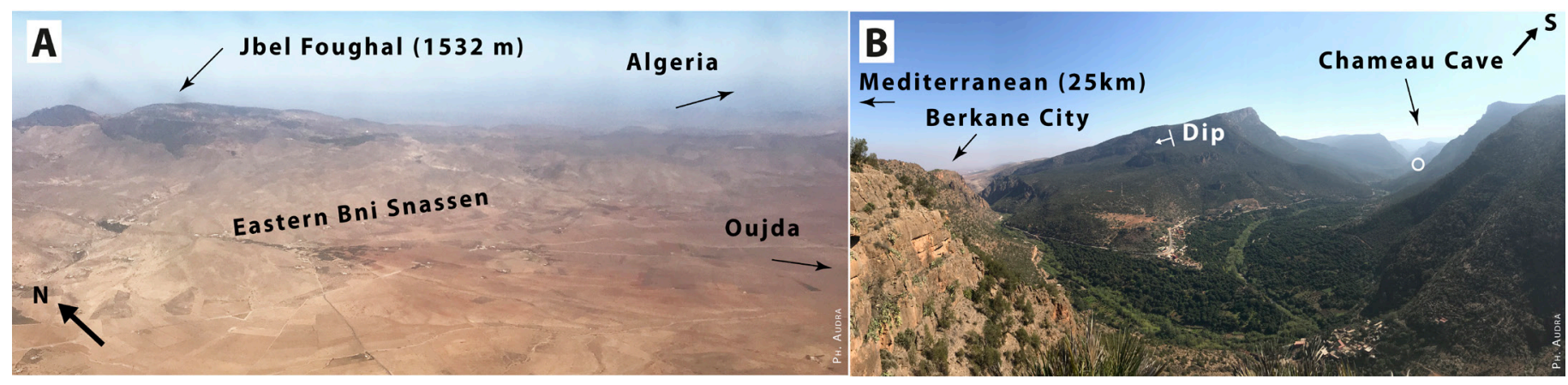

Fig.1. A) Aerial view from the South of Eastern Bni Snassen Massif showing its highest summit, the Jbel Foughal. Chameau Cave is located to the north, on the opposite Mediterranean slopes of the mountain, which receives more rainfall; B) View of the Zegzel Valley, showing the bamboo riparian formation (light green), the medlar plantations (dark green), and on the slopes the mediterranean bushes and forests growing of Jurassic limestones. 
its beauty, its long history, and the presence of permanent water made it famous even beyond the region. The cave has obviously been known for ages. A French soldier, Joannis (1915) made a sketch and the first description of the cave and interpretation of its hydrology. The cave was first opened as a show cave with electricity lightning in 1948, by André Amélineau from the Speleological Society of Morocco (SSM) in collaboration with the Oujda Touristic Board (Camus \& Lamouroux, 1981). Touristic installations were renewed at the end of the 1980'. Thirty years after its planned opening, it is scheduled in the near future to effectively open and to become updated by new lighting technology and didactic guiding using Wi-Fi network. Cave monitoring and scientific studies are also carried out as part of cave management plan. Several cave surveys have been made (Joannis, 1915; Cantet, 1976; Lips, 1981); the upstream sump (S2 on Fig. 2, 3B) was first dove in 1971 (Cantet, 1976) and crossed in 1982 (Boenlé, 1982, 1983). A third sump was reach in 2018 by Spanish divers. In 2017, the authors (PA, MR, and other cave colleagues) reached a new upper level, the Nadia Gallery (Audra et al. 2021).
Cave geology and geomorphology

Cave geomorphology and hydrology were studied by Tayebi (2011), showing a complex evolution of the cave levels in relationship to base-level changes. Different generations of fluvial sediments can be seen in the cave. They partly consist of allogenic coarse material, from sand to pebbles, brought in from upstream catchments by the underground flow of the river. Beyond their diversity, passages commonly display walls and ceiling features smoothed by condensationcorrosion and wavy rocky walls generally devoid of speleothems (Fig. 3C). When present, speleothems are generally old and inactive, and display a deeply corroded inner lamination. They are mostly preserved in the lower part of walls that are less affected by condensation-corrosion, or as discrete remnants when located in higher parts of the wall and ceiling. A large part of the floor is covered by guano deposits (Fig. 3D), except along the lower level, which is seasonally washed by the temporary flow of the river, and along the touristic path where it has been strongly reworked.

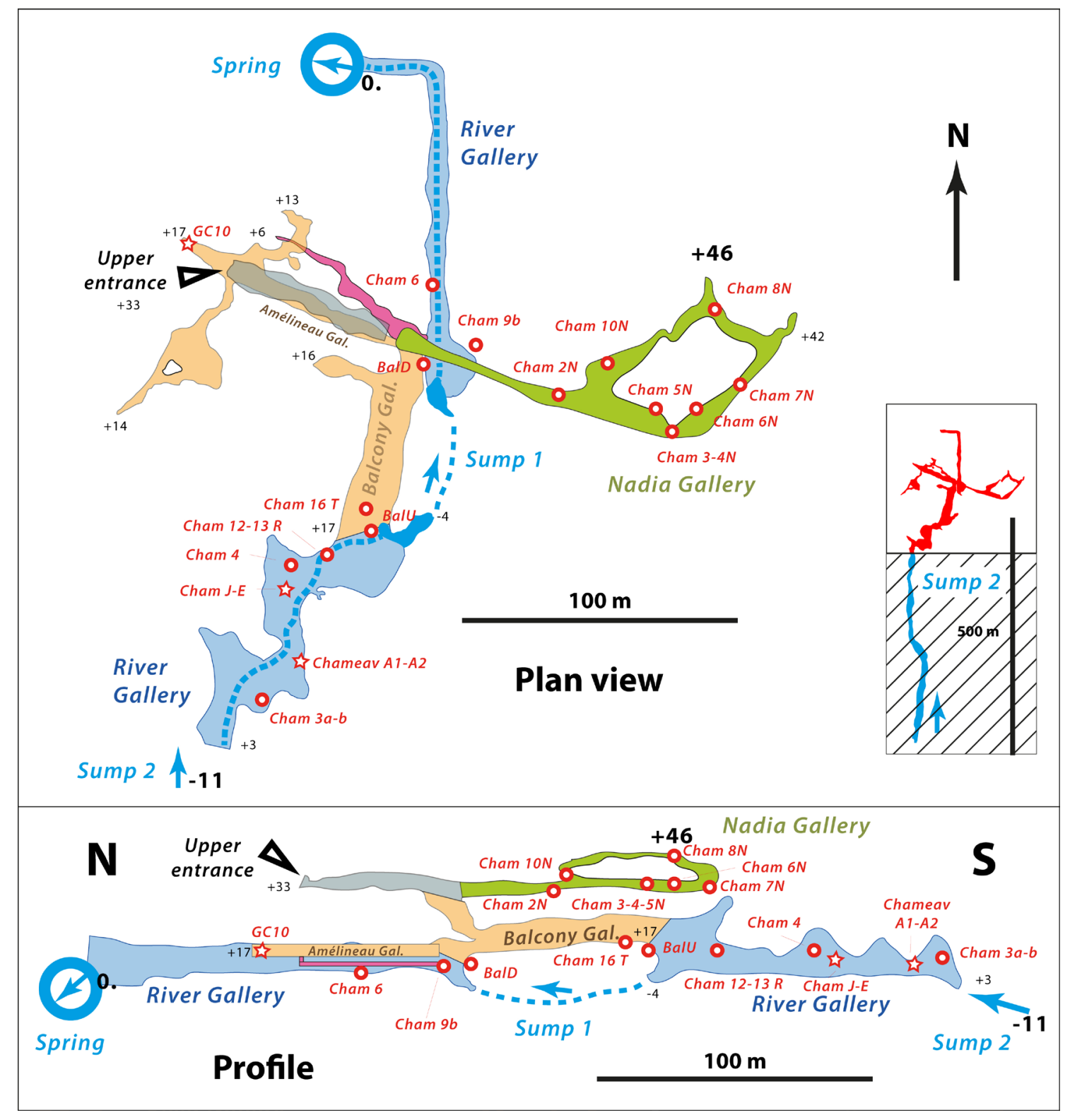

Fig. 2. Simplified survey of Chameau Cave, with location of the collected samples along with their reference number. Samples for mineralogy are labelled "Cham" and indicated as red circles. Samples for U-Th dating are indicated as red stars. 


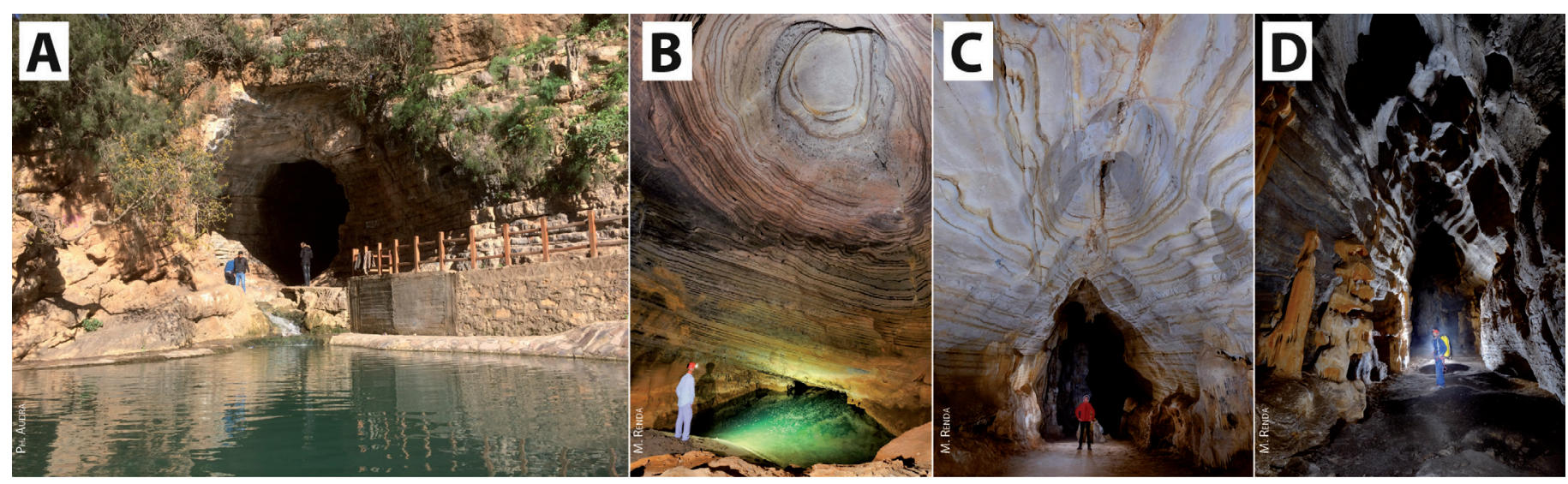

Fig. 3. Typical passage features in the Chameau Cave. A) Lower entrance with temporary active outflow, March 2018; B) Upstream sump covered with calcite rafts produced by $\mathrm{CO}_{2}$ degassing leading to oversaturation during low water levels. During high water, coarse sands (under the person's feet) are brought from upstream; large condensation-corrosion cupola on the ceiling; C) Amélineau Gallery, with clear walls etched by condensation-corrosion. Remnants of old fluvial sediments and corroded flowstones are attached to the wall. The floor was smoothed for touristic path, reworking the old fluvial sediments and the guano deposits; D) Dry passage in the Nadia Gallery. Etched walls and speleothems relicts are the result of strong condensation-corrosion; the floor is covered with old guano and recent guano piles.

\section{Bat colonies}

Large bat colonies were once present in Chameau Cave, as mentioned by past explorers (Joannis, 1915; Guyot, 1984), and as shown by large guano cones, several meters high and extending downward along the slopes of the river, $15 \mathrm{~m}$ lower. In the 1950s, six species of bats were identified (Brosset, 1960): greater horseshoe bat (Rhinolophus ferrum-equinum), Mehely's horseshoe bat (Rhinolophus mehelyi), mouseeared bat (Myotis myotis), Schreibers's long-fingered bat (Miniopterus schreibersii), Blasius's horseshoe bat (Rhinolophus blasii), and lesser horseshoe bat (Rhinolophus hipposeridos). The largest colonies reached several hundreds of individuals for Mehely's horseshoe bat and more than 1,000 individuals for the mouse-eared bat. All species are insect-eating and forage along the open spaces of the Zegzel Valley. Depending on species, the cave was used for lair, maternity, and swarming (Brosset, 1960; Dietz et al., 2007; Flaquer Sanchez \& Puig Montserrat, 2012). Since the gating of both entrances, in the 1980s (or possibly before) when the cave was reconfigured, only some dozen of individuals are still present. Guano deposits were probably once significant; however continuous mining by local inhabitants through history and leveling made for the show cave destroyed their original shape, except in the River Gallery between Sumps 1 and 2, which is rather difficult to access. In the newly discovered Nadia Gallery, guano covers most of the surface, however its thickness remains unknown. Here, an "old" individual skull of Rhinolophus mehelyi has been identified (Dodelin, 2002).

\section{Sampling sites description}

The cave harbors extensive guano deposits, mainly in Nadia Gallery, and large guano heaps in River Gallery (Hill \& Forti, 1997). The upper part of some of these heaps were recently active, some are still active. Guano-related minerals are present as fields of yellow popcorn, as a cone of gold-like candy floss, as widespread brown or yellowish crusts, and as very thick (up to $4 \mathrm{~m}$ ) light grey and soft-porous completely mineralized deposits. All sampled sites are described hereafter, and their location shown in Fig. 2. In River and Nadia galleries, sampling was made on the surface in discrete spots corresponding to recent or old guano deposits, or to phosphate accumulations. The perched Balcony Gallery, which is cut at both ends by the River Gallery, offers the opportunity to study the whole sediment profile, several meters-thick, partly composed of phosphate accumulations.

River Gallery. The River Gallery is split in two sections by the first sump (S1). The downstream segment extends between $\mathrm{S} 1$ and lower entrance; the upstream segment extends between second sump (S2) and S1 and is accessible from the end of Balcony Gallery by a $10 \mathrm{~m}$ shaft (Fig. 2). This gallery is temporarily active and discharge that sometimes can exceed $1 \mathrm{~m}^{3} / \mathrm{s}$ with a torrential flow, causes eventually back flooding of the upstream section creating a continuous lake more than $10 \mathrm{~m}$ deep. Consequently, fast-flow erosion has removed most of the sediments and only hard crusts have been preserved in the flooding area. The upper part of the gallery, which is sometimes higher than $20 \mathrm{~m}$, remains above the highwater level, allowing the conservation of sediments and guano deposits, whether old or recent. Sampling sites are described from upstream.

Cham 3 (Fig. 4A-E). Downstream from S2, about $15 \mathrm{~m}$ above the riverbed, a large alcove extends laterally on the right bank, below a $25 \mathrm{~m}$-high cupola harboring a bat colony. A large guano cone of more than $10 \mathrm{~m}$ in diameter extends downwards until it reaches floodwater level, where it is periodically washed away. Fresh guano is present on top (Fig. $4 \mathrm{~A}-\mathrm{C}$ ). This restricted area is wet from condensation dripping, whereas other parts are dry. Light yellowishwhitish lumpy minerals (Cham 3a) are growing on the guano surface. Black remnants of insect chitins are still visible (Fig. 4C).

Cham 4 (Fig. 4F). It is located downstream, in a same type of position like Cham 3: a lateral alcove above flood level, with old guano on the sides and fresh guano on top, below a high cupola where stalagmites are fed by condensation dripping (not visible in the picture). The central wet zone shows only guano 
covered with microbial mats. About $3 \mathrm{~m}$ from the dripping point, the guano is dry and covered by yellow lumpy aggregates. An intermediate area, about $30 \mathrm{~cm}$ in width, shows a transition with a rather sharp limit between microbial and the yellow lumpy aggregates areas (scale is $5 \mathrm{~cm}$ long).

Cham 12R and 13R (Fig. 4G-K) were collected on the left bank, a few meters before connection with Balcony Gallery, from a several meters-long outcrop dipping parallel to the slope and covering large rock boulders. The bulk sample consists of light grey material
(Cham 12R), very porous but extremely hard, covered with a hard-dark brown crust, a few millimeters thick (Cham 13R, view from the upper face).

Cham 9b (Fig. 4L) comes from the downstream part of the River Gallery, close to the outlet of S1, above the floodwater level. A bleached area coats an old guano pot.

Cham 6 (Fig. 4M-N) was sampled in the downstream part of the River Gallery. Below a (probably iron-) phosphate crust, an old corroded calcite, containing an interlayered black seam.
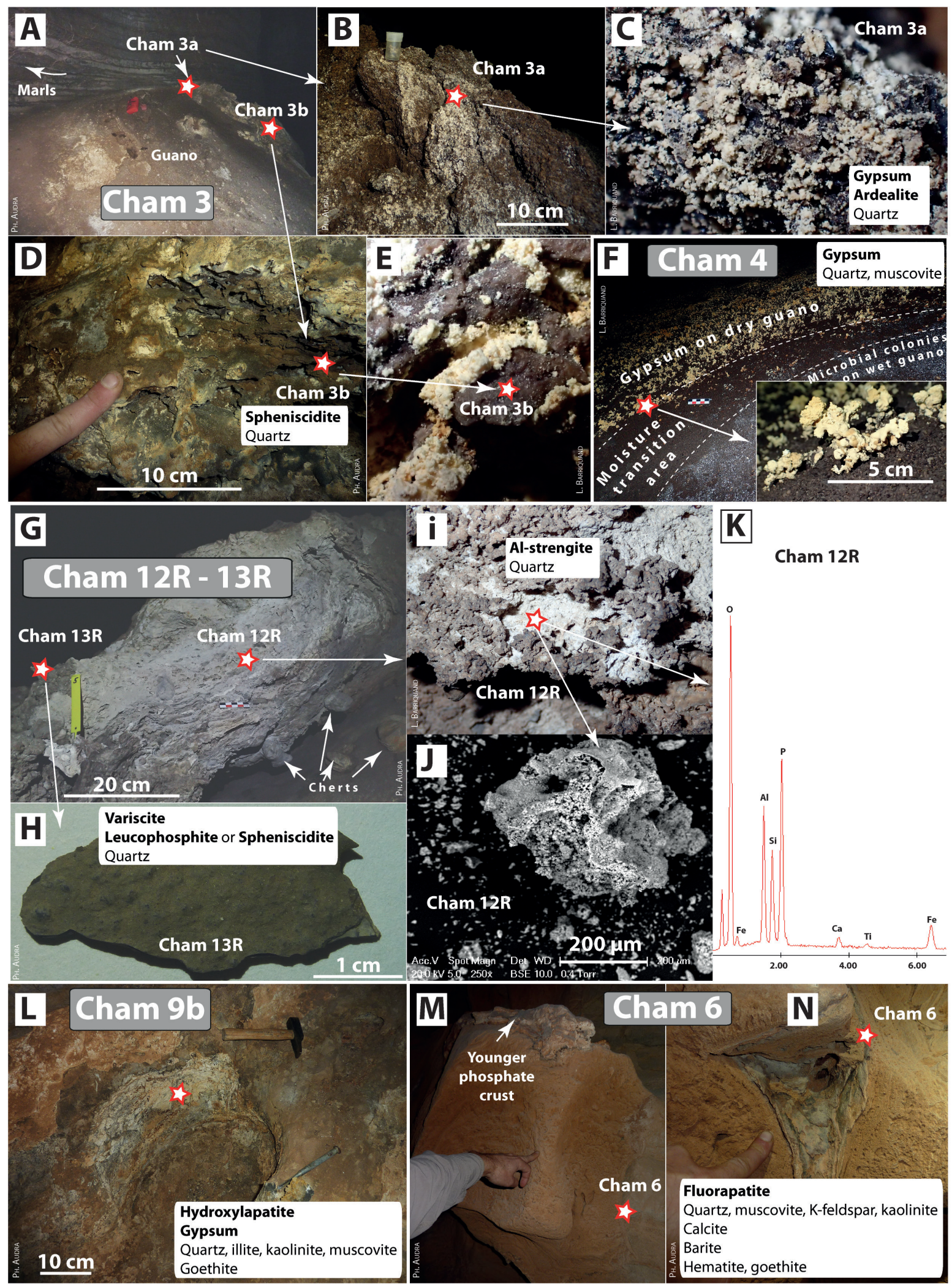

Fig. 4. Samples of River Gallery, with mineralogical results. See text for details. 
Nadia Gallery. This is a perched dry passage that was recently discovered in 2018. Consequently, and contrary to the other passages, all deposits are intact and have been protected. They comprise (i) old and recent guano, (ii) deeply corroded speleothems, (iii) old fluvial deposits, which are generally buried or present in discrete places as patches in niches, (iv) autochtonous fine deposits made by disaggregation of the wall shale partings, and (v) recent surface deposits injected from connections to the surface, located at the ends of the gallery (Fig. 3D).

Cham 2N (Fig. 5A) is from a cone of gypsum, several meters in diameter and more than $1 \mathrm{~m}$ in height. It is built of an accumulation of sparkling, gold-like, fluffy-light pellets that resemble candy-floss (Martini $\&$ Kavalieris, 1978). The cone is located directly below an $8 \mathrm{~m}$-high cupola. Note on the picture the dark marks of bats roosts in the cupola, most probably consisting of apatite-group minerals.

Cham 6N (Fig. 5B) was recovered from a soft grey deposit located at the foot of the wall, which is made of marly limestone beds interbedded with thin shale layers. It is clear that at least part of the deposits resulted by condensation-corrosion of the wall. Insoluble particles detach, fall down, and accumulate at the foot of the wall, and eventually are mixed with other materials by a small runoff stream in the center of the gallery, namely guano and possibly old reworked fluvial sediments.

Cham 3N-4N (Fig. 5C). In the central part of the gallery, a grey hard vuggy layer (Cham 4N), which contains a softer upper part, is partly eroded by dripping holes, and is covered by a $\sim 8 \mathrm{~cm}$-thick soft yellow layer, locally mixed with old guano (Cham $3 \mathrm{~N}$ ).

Cham 5N (Fig. 5D) comes from a perched lateral niche and occurs as a hard-grey vuggy crust about $20 \mathrm{~cm}$ in thickness. Visually, it is very similar to the grey layer in Cham $4 \mathrm{~N}$.

Cham 7N (Fig. 5E). This occurrence is located at the end of the gallery, where temporary active dripping has eroded the soft grey silts, generating earth pillars. Cham $7 \mathrm{~N}$ corresponds to the lighter hard hat.
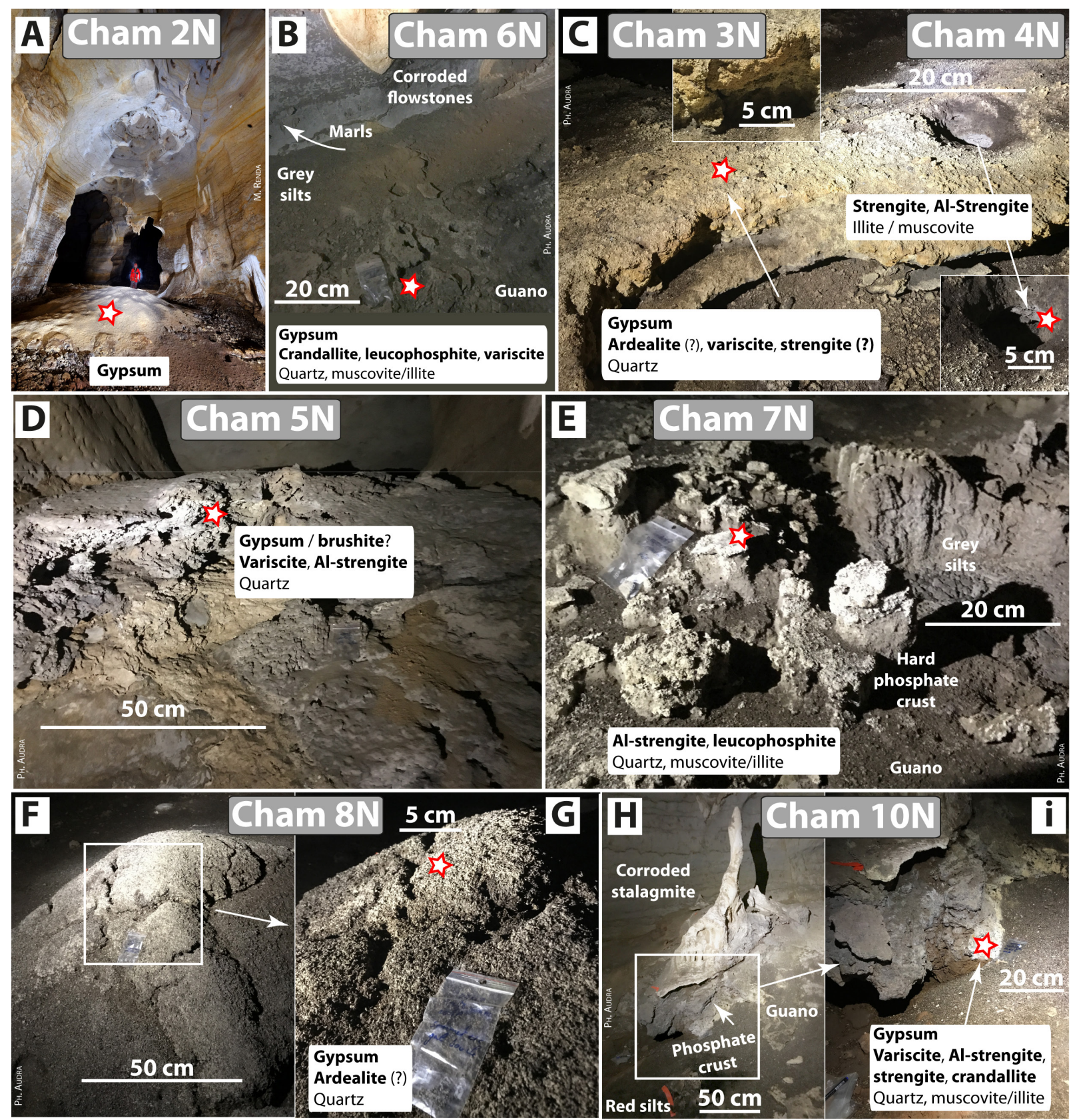

Fig. 5. Samples of Nadia Gallery, with mineralogical results. See text for details. 
Cham 8N (Fig. 5F, 5G) was recovered from the highest place of the lateral loop, which is also the highest point of the cave. A $1 \mathrm{~m}$-high fresh guano pile is covered with pale whitish-yellowish lumpy minerals.

Cham 10N (Fig. 5H, 5I). This occurrence is located at the first cross of the lateral loop. Here, a deeply corroded stalagmite covers a hard-grey crust, similar to Cham $4 \mathrm{~N}$ and $5 \mathrm{~N}$, which in turn rests on red-brown clay deposits. The latter are locally covered by a thin white crust (Cham 10N).

Balcony Gallery is the innermost dry level, perched about $10 \mathrm{~m}$ above the two segments of the River Gallery. Contrary to other sites, where minerals have been sampled on the surface, this gallery shows two profiles of its filling resulting from a later incision of the river after the abandonment of the Balcony level. The floor of the gallery is covered with both recent and old guano, which has been leveled for the tourist trails (Fig. 6). Some small patches of old deposits are still visible in place, corresponding to phosphates, speleothems, and fluvial material. The profiles show a sediment thickness of about $5 \mathrm{~m}$, with a mainly fluvial sequence at the bottom, and a mainly phosphatic sequence on top. Large blocks (up to $4 \mathrm{~m}$ long), detached from the roof, are mixed in both sequences.

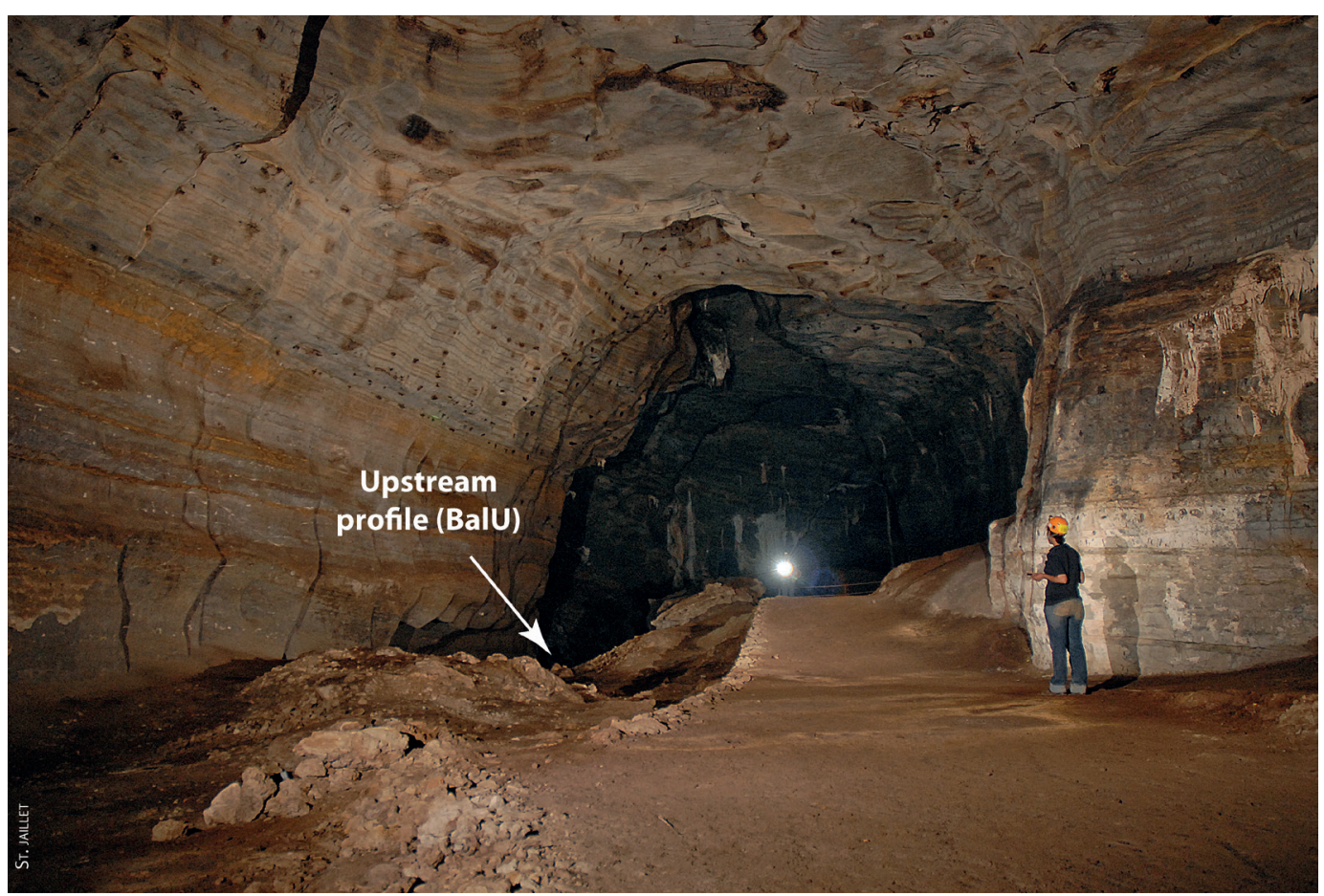

Fig. 6. The Balcony Gallery, view toward upstream. It is covered with a thin layer of old and fresh guano. Below, a very thick $(4 \mathrm{~m})$ deposit of soft porous aggregates of phosphates is visible at the extremities, where vertical profiles cut through the entire passage.

Balcony Gallery, downstream profile (BalD Fig. 7). This profile corresponds to the late incision of the abandoned Balcony Gallery by the temporary active river, which flows at its foot. The profile shows the entire sedimentary pile. It is about $8 \mathrm{~m}$ wide and thick, however part of it is missing to the NW, destroyed by the tourist trail. Three main units can be identified, from bottom to top (Fig. 7A). The Lower Unit (A) mainly consists of fluvial sediments, with coarse sand packing metric blocks and grading up into red clay without blocks. Blocks are blunted; however, according to their large size, this smoothing was acquired by crypto-corrosion inside the sedimentary deposit rather than by any fluvial transport. The Intermediate Unit (B) also shows large blunted blocks packed into yellowish coarse-grained sands and laminated clays. This unit is located at the bottom; however, it is probably lying against the Lower Unit (A) and thus younger than the Lower Unit. The Upper Unit (C) is located on top but also extends to the bottom on the NW side along the tourist trail. The unit consists of a 2-3 m-thick compact grey "sandy" porous material, with few blocks of smaller size compared to other units. It is covered by a thin and hard dark brown crust. Several samples were collected at the contact between the Intermediate and Upper Units, and on top of the Upper Unit.

The Intermediate Unit shows a grey material (BalD 1). A hard dark-brown crust (BalD 2) marks its limit with the Upper Unit C. Above the red clay and sand, a carbonate block decomposes as onion skins, with a lighter deeply weathered peel (BalD 3b) and a thin black layer (BalD 3a) at the contact of the intact block (Fig. 7B). The Upper Unit mainly consists of a thick compact grey "sandy" porous material, with some visible lamination and sometimes boxwork structure (BalD 5, Fig. 7C). It is capped by a thinly laminated, thin $(\sim 5 \mathrm{~mm})$, brown crust (BalD 6). We also found a pink crust of limited extension (BalD 4, Fig. 7D).

Balcony Gallery, upstream profile (BalU - Fig. 8). The profile at the upstream end of the Balcony Gallery extends vertically along a shaft resulting from river incision and thus only accessible using rope technics. Contrary to the profile BalD located on the downstream end of the Balcony Gallery, here only the Upper Unit (C) of the profile remains, its lower part have been scoured by the river. Only a thin crust attached to the rocky wall witnesses its past extension. The sediment 
fill extends along the whole width of the gallery, i.e. more than $10 \mathrm{~m}$, the remaining thickness being about 3-4 m.

The remnant of the presumed Lower Unit is limited to a thin brown crust (BalU 3) attached to the wall. The Upper Unit (C) is composed of a very homogenous grey-white sandy material, very similar to the neighboring Cham $12 \mathrm{R}$ in the River Gallery, and to BalD 5 in the downstream profile. BalU 1 sample is located $1 \mathrm{~m}$ from top; a thin black layer (BalU 2) $3 \mathrm{~m}$ below the top; and on top, a block of hard grey vuggy material (Cham 16T).
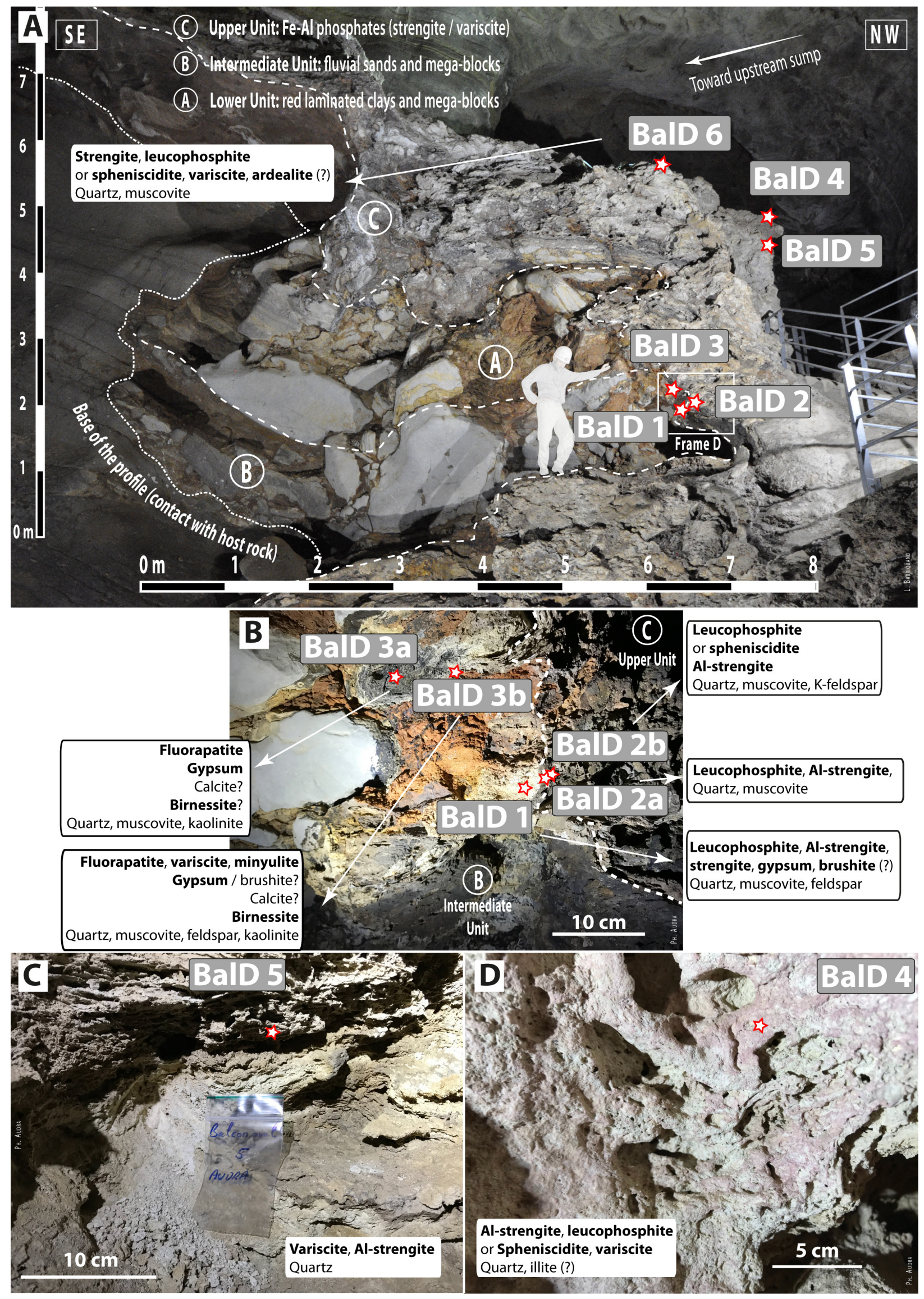

Fig. 7. Samples of the downstream profile in the Balcony Gallery, with mineralogical results. See text for details. 


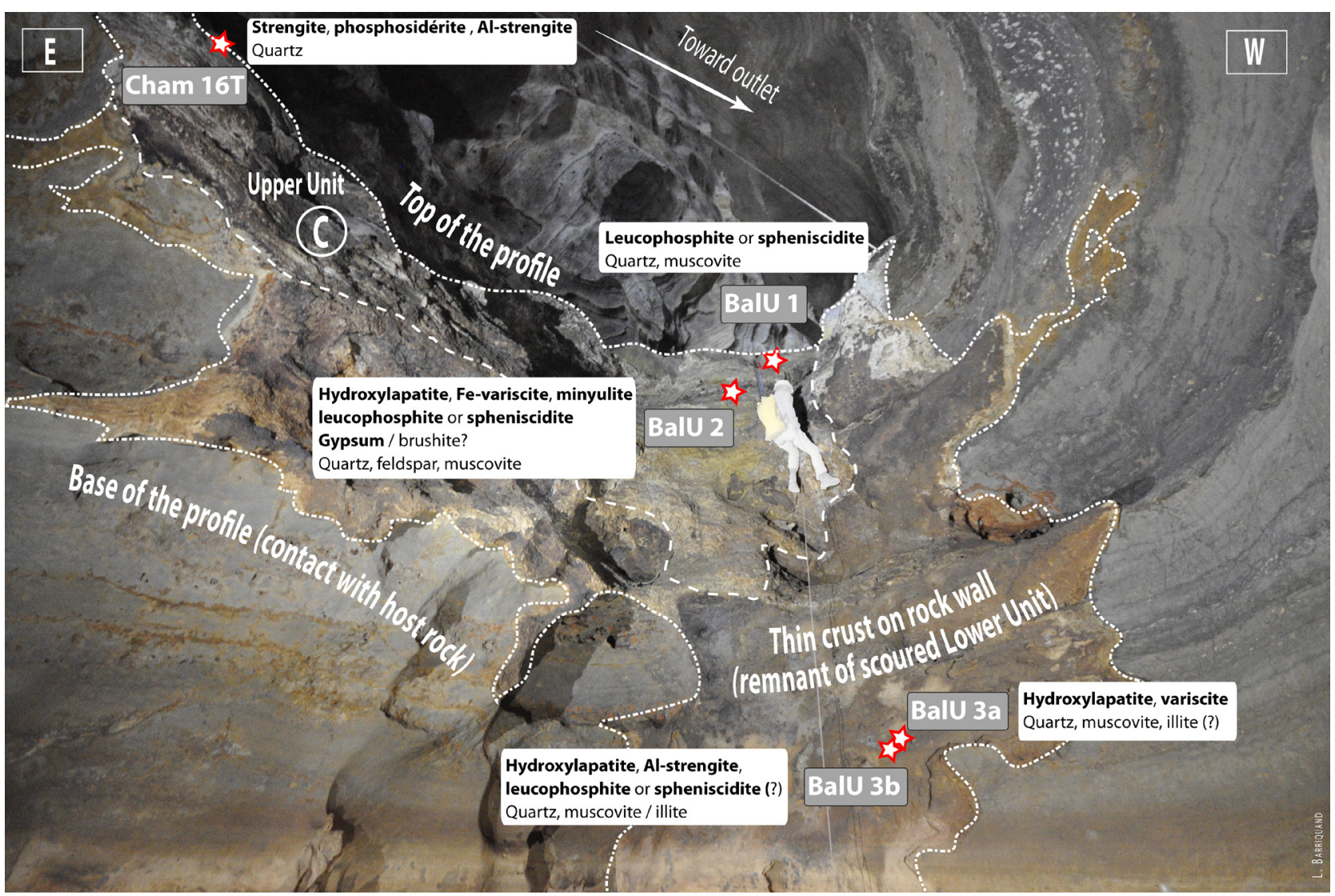

Fig. 8. Samples of the upstream profile in the Balcony Gallery, with mineralogical results. Caver on rope for scale. See text for details.

\section{METHODS}

To identify the minerals and to understand their genesis conditions, we collected samples and documented their environment, mainly in the River and Nadia galleries. For conservation purposes, sampling was done from broken or loose pieces.

\section{Mineralogical studies}

Mineralogical investigations include phase identification using powder X-ray diffraction (XRD) analyses, which were carried out at the X-ray services, Centre Européen de Recherche et d'Enseignement de Géosciences de 1'Environnement (CEREGE) and Centre Interdisciplinaire de Nanoscience de Marseille (CINaM), CNRS - Aix Marseille University. XRD patterns were recorded mainly on two diffractometers; Philips, $\theta-2 \theta$ geometry, Co radiation $(\lambda=0.179 \mathrm{~nm})$, and Panalytical X'Pert Pro MPD $\theta-\theta$ geometry, $\mathrm{Cu}$ radiation $(\lambda=0.15418 \mathrm{~nm})$. The diffraction patterns were then analyzed using the X'Pert Highscore program and the PDF-2 - ICDD database (released 2004). In addition, XRD analyzes were made on sample Cham 6 before and after decarbonatation using diluted $\mathrm{HCl}$, in order to remove the speleothem calcite compound around the black seam.

For some samples, scanning electron microscope (SEM) imaging was performed with a Philips ESEM 30, at an acceleration voltage of $15 \mathrm{kV}$ at the Plateforme de Recherche Analytique Technologique et Imagerie (PRATIM), Aix Marseille University. Coupled detector SSD X-ray Apollo 10 EDAX allows microanalysis by identifying chemical composition of samples. A SEM - Jeol JSM 6340F and a TEM - Jeol JEM 2010 with
Bruker Esprit EDX detector were used at CINaM Laboratory for complementary investigations. All samples were also examined under 10x binocular.

\section{Environmental monitoring in the cave}

Some preliminary measures and monitoring of microclimatic parameters were done. We acquired temperature (T) of cave air and water, relative humidity (RH), airflow velocity (V), and carbon dioxide concentration $\left(\mathrm{CO}_{2}\right)$. For punctual measurements, we used Testo 425 and Testo 888 anemometers (V, $\mathrm{T})$, Senseair pSENSE analyzer ( $\left.\mathrm{T}, \mathrm{RH}, \mathrm{CO}_{2}\right)$; and for continuous monitoring dataloggers Reefnet Sensus (T) and Temtop TemLog $20 \mathrm{H}(\mathrm{T}, \mathrm{RH})$. The detailed exploitation of these climatic data is beyond the topic of this paper. However, in the Microclimate distribution subchapter a general overview of the environmental conditions and the controlling processes is provided.

\section{Speleothems sampling and dating}

In order to determine the age limits of the phosphate deposits, speleothems that underly or overly these accumulations were sampled and dated by U/Th radiometric method by three laboratories: (i) samples GC10-10A, $-10 \mathrm{~B},-8 \mathrm{~B}$, and $-8 \mathrm{~A}$, were provided from stalagmites covering the final plug of Amélineau Gallery, and analyzed at Laboratoire des Sciences du Climat et de 1'Environnement (LSCE), Gif-sur-Yvette, France. The analytical procedure is detailed in PonsBranchu et al. (2014); (ii) samples Chameav A1 and -A2 came from a piece of a corroded flowstone from the upstream part of River Gallery, and ages were obtained at the join Polish-Czech Laboratory of Institute of Geological Sciences, Polish Academy of Sciences, 
Warsaw, Poland and Institute of Geology, Czech Academy of Sciences, Prague, Czech Republic. The analytical procedure is detailed in Gorka \& Hercman (2002); (iii) ages for 2 fragments (ChamJ and ChamE) from a corroded flowstone covered by old phosphates and guano in upstream part of River Gallery were determined at the Institute of Global Environmental Change (IGEC), Xi'an Jiaotong University, China. The analytical procedure is available in Cheng et al. (2013).

\section{RESULTS}

\section{Microclimate distribution}

The Chameau Cave has an average temperature of about $19^{\circ} \mathrm{C}$. Its microclimate is strongly influenced by the two entrances situated at more than $30 \mathrm{~m}$ relief between them, and a more isolated inner part closed by the Sump S2. The sump temperature is controlled by both cool meteoric inflow after severe storms, and by the geothermal gradient during long recessions (Audra, 2017). Due to its water temperature ranging between 21 and $27^{\circ} \mathrm{C}$, it constitutes a "hot spot" in the inner part of the cave that significantly contributes to cave warming and moistening (Barriquand et al., 2018). Consequently, two types of draught are observed into the cave: (i) a strong air circulation due to chimney-effect between both entrances, whose direction alternates seasonally, or daily in the intermediate season. Air-flow velocity may reach $1.6 \mathrm{~m} / \mathrm{s}$ in the narrow passages such as the upper entrance door; (ii) permanent convection cells in blind passages, such as Nadia and Balcony galleries before Sump 2. Here velocities decrease in the range of 0.05 to $0.3 \mathrm{~m} / \mathrm{s}$. However, due to the large section of these cave passages, even such low velocities correspond to very high discharge, up to $7 \mathrm{~m}^{3} / \mathrm{s}$ in Balcony Gallery. The temperature amplitude reduces from the cave entrances $\left(\sim 20^{\circ} \mathrm{C}\right)$ to the Sump $2\left(\sim 5^{\circ} \mathrm{C}\right)$, where daily amplitude is lower than $0.5^{\circ} \mathrm{C}$. Most of the cave appears extremely dry, even dusty, as in any open cave in semi-arid environment. In winter, cold air enters the cave; upon warming, it dries any passage along which it flows; in summer, extremely dry surface air entering the cave also dries the cave, since the air cannot reach the dew point upon cooling (Cailhol et al., 2019). Based on punctual measurements of airflow in winter conditions, a daily evaporation of about $1,800 \mathrm{~L}$ was calculated for the entire cave (Barriquand et al., 2018). However, even under such conditions, some possibility of moisture remains in specific areas where condensation occurs, such as in the blind passage leading from Balcony Gallery to Sump 2. Here, in winter, a permanent convection cell, indirectly fed by cool air coming from outside, warms up upon entering the cave and dries the floor. At the end of the loop above the "hot" sump, the air is heated and moisturized. Then it starts to rise, eventually leaving the cave along the ceiling. In this return part of the loop, it produces intense condensation on the cooler ceiling and upper walls. Strong moisture and intense dripping clearly show it. In the intermediate season, such wet airflow can even reach the upper entrance and flood it with damp air. Along the upstream part of the cave, from Sump 2 to Balcony Gallery, the calculated volume of water that condenses along the ceiling can reach 2,700 L/day in winter. Even if most of this condensation re-evaporates upon reaching the floor, some discrete spots such as high cupolas can produce enough condensation to keep their floor wet over limited surfaces. This permanent moisture below cupolas, where bats are swarming, can account for a gradual decay of guano into phosphates. Yet, extended dry conditions are generally prevailing in most of the cave.

\section{Mineralogical results}

The mineralogical phases, as identified from the XRD coupled with the electron microscopy observation are presented in Table 1, and detailed thereafter. Guanorelated minerals are displays in bold characters, and detailed description of the analysis is given in the Supplementary Information. The process of identification of the mineralogical phases through XRD becomes very complex when many different phases are present (diffraction peaks overlapping) and when in small amounts (diffraction peaks not visible). Most of the minerals listed in Table 1 were clearly definable, but some remain uncertain (marked with "?" in the Table 1). For example, differentiating spheniscidite from leucophosphite (at least for the measured samples) by XRD is difficult since in some cases the pics are too small to clearly identify the mineral.

\section{River Gallery}

Cham $3 \mathrm{a}$ is composed of quartz, gypsum, and ardealite. Downward, some steep places partly covered with old dusty guano show the rocky basement, which is covered by similar gypsum-ardealite lumps growing on a very hard brown crust (Cham $3 \mathrm{~b}$ ). In addition to detrital material (quartz, muscovite) the crust most probably consist of spheniscidite, or possibly leucophosphite (Fig. 4A-E). The yellow lumps (Cham 4) are made of gypsum (Fig. 4F). The bulk material of Cham $12 \mathrm{R}$ is composed of quartz grains and Alrich strengite (Fig. $4 \mathrm{G}$ to $4 \mathrm{~K}$ ). SEM image shows small grains $(1-5 \mu \mathrm{m})$ agglomerated in masses $(\sim 400 \mu \mathrm{m})$, associated with quartz needles showing hexagonal faces. EDX analysis indicates the presence of $\mathrm{P}, \mathrm{Al}$, $\mathrm{Fe}$, associated with $\mathrm{Si}, \mathrm{Ca}$, and traces of Ti. Its brown crust Cham $13 \mathrm{R}$ is mainly composed of variscite, and leucophosphite or spheniscidite. Accordingly, most of this material is made of quartz grains mixed with Al-Fe phosphates. Cham 9b is mainly composed of hydroxylapatite, associated with gypsum, and detrital minerals (Fig. 4L). Cham 6 is mainly composed of fluorapatite, with traces of baryte, iron oxyhydroxides, and detrital material (Fig. 4M-N).

\section{Nadia Gallery}

The candy-floss-like cone (Cham $2 \mathrm{~N}$ ) is made of pure gypsum (Audra et al., 2016) (Fig. 5A).

Cham $6 \mathrm{~N}$ is a mixture of leucophosphite, variscite, crandallite, some gypsum, and detrital material (quartz, muscovite/illite) (Fig. 5B). The lower hard 
Table 1. Analytical results of guano-related minerals. Detrital minerals and carbonates are not reported here $(\bullet)$ : Abundant or main compound; (x): present; (?): possible. Mineral keys: Secondary clay (S-C) - KA: kaolinite $\left[\mathrm{Al}_{2}\left(\mathrm{Si}_{2} \mathrm{O}_{5}\right)(\mathrm{OH})_{4}\right]$; Sulfates (SU) - GY: gypsum [CaSO $\left.{ }_{4} \cdot 2 \mathrm{H}_{2} \mathrm{O}\right]$; $\mathrm{BA}$ : baryte $\left[\mathrm{BaSO}_{4} \cdot 2 \mathrm{H}_{2} \mathrm{O}\right]$. Sulfates-phosphates $(\mathrm{S}-\mathrm{P})-\mathrm{AR}$ : ardealite $\left[\mathrm{Ca}_{2}\left(\mathrm{PO}_{3} \mathrm{OH}\right)\left(\mathrm{SO}_{4}\right) \cdot 4 \mathrm{H}_{2} \mathrm{O}\right]$. Phosphates - BR: brushite $\left[\mathrm{Ca}\left(\mathrm{PO}{ }_{3} \mathrm{OH}\right) \cdot 2 \mathrm{H}_{2} \mathrm{O}\right]$; $\mathrm{HA}$ : hydroxylapatite $\left[\mathrm{Ca}_{5}\left(\mathrm{PO}_{4}\right)_{3}(\mathrm{OH})\right]$; FA: fluorapatite $\left[\mathrm{Ca}_{5}\left(\mathrm{PO}_{4}\right)_{3} \mathrm{~F}\right]$; VA: variscite $\left[\mathrm{AlPO}{ }_{4} \cdot 2 \mathrm{H}_{2} \mathrm{O}\right]$; AS: Al-rich strengite* $\left[(\mathrm{Fe}, \mathrm{Al}) \mathrm{PO}_{4} \cdot 2 \mathrm{H}_{2} \mathrm{O}\right]$; ST: strengite $\left[\mathrm{FePO}_{4} \cdot 2 \mathrm{H}_{2} \mathrm{O}\right] ; \mathrm{SP} / \mathrm{LE}$ : spheniscidite $\left[\left(\mathrm{NH}_{4}, \mathrm{~K}\right)\left(\mathrm{Fe}^{3+}, \mathrm{Al}\right)_{2}\left(\mathrm{PO}_{4}\right)_{2}(\mathrm{OH}) \cdot 2 \mathrm{H}_{2} \mathrm{O}\right]$ or leucophosphite $\left[\mathrm{KFe}^{3+}{ }_{2}\left(\mathrm{PO}_{4}\right)_{2}(\mathrm{OH}) \cdot 2 \mathrm{H}_{2} \mathrm{O}\right] ; \mathrm{Ml}^{2}$ minyulite $\left[\mathrm{KAl}_{2}\left(\mathrm{PO}_{4}\right)_{2}(\mathrm{OH}, \mathrm{F}) \cdot 4 \mathrm{H}_{2} \mathrm{O}\right] ; \mathrm{CR}$ : crandallite $\left[\mathrm{CaAl}_{3}\left(\mathrm{PO}_{4}\right)\left(\mathrm{PO} \mathrm{O}_{3} \mathrm{OH}\right)(\mathrm{OH})_{6}\right]$; PS: phosphosiderite $\left[\mathrm{FePO}_{4} \cdot 2 \mathrm{H}_{2} \mathrm{O}\right]$. Oxyhydroxides $(\mathrm{O}-\mathrm{H})-\mathrm{GO}$ : goethite $\left[\alpha-\mathrm{Fe}^{3+} \mathrm{O}(\mathrm{OH})\right]$; HE: hematite $\left[\mathrm{Fe}_{2} \mathrm{O}_{3}\right]$; BI: birnessite $\left[(\mathrm{Na}, \mathrm{Ca})_{0.5}\left(\mathrm{Mn}^{4+}, \mathrm{Mn}^{3+}\right)_{2} \mathrm{O}_{4} \cdot 1.5 \mathrm{H}_{2} \mathrm{O}\right]$.

\begin{tabular}{|c|c|c|c|c|c|c|c|c|c|c|c|c|c|c|c|c|c|c|}
\hline \multirow[b]{2}{*}{ Sample no. } & \multirow{2}{*}{$\begin{array}{c}\text { Description } \\
\text { Mineral code }>>\end{array}$} & \multirow{2}{*}{\begin{tabular}{l|l} 
S-C \\
KA
\end{tabular}} & \multicolumn{2}{|c|}{ SU } & \multirow{2}{*}{$\begin{array}{l}\text { S-P } \\
\text { AR }\end{array}$} & \multicolumn{10}{|c|}{ Phosphates } & \multicolumn{3}{|c|}{$\mathbf{O}-\mathbf{H}$} \\
\hline & & & GY & BA & & BR & HA & FA & VA & AS & ST & $\begin{array}{l}\text { SP / } \\
\text { LE }\end{array}$ & MI & $\mathbf{C R}$ & PS & GO & HE & BI \\
\hline Cham 3a & Yellow popcorns & & $\bullet$ & & $\mathrm{x}$ & & & & & & & & & & & & & \\
\hline Cham 3b & Hard brown crust & & & & & & & & & & & $\mathrm{x}$ & & & & & & \\
\hline Cham 4 & Yellow popcorns & & $\bullet$ & & & & & & & & & & & & & & & \\
\hline Cham 12R & Quartzose sand block & & & & & & & & & $\bullet$ & & & & & & & & \\
\hline Cham 13R & Thin black crust & & & & & & & & $\bullet$ & & & $\bullet$ & & & & & & \\
\hline Cham 6 & $\begin{array}{c}\text { Black layer } \\
\text { interbedded in calcite }\end{array}$ & $\mathrm{x}$ & & $\mathrm{x}$ & & & & $\bullet$ & & & & & & & & $\mathrm{x}$ & $\mathrm{x}$ & \\
\hline Cham 9b & Crust in guano pot & $\mathrm{x}$ & $\mathrm{x}$ & & & & $\bullet$ & & & & & & & & & $\mathrm{x}$ & & \\
\hline Cham 2N & Gypsum cone & & $\bullet$ & & & & & & & & & & & & & & & \\
\hline Cham 3N & Yellow crust & & $\bullet$ & & $?$ & & & & $\bullet$ & & $?$ & & & & & & & \\
\hline Cham $4 \mathrm{~N}$ & $\begin{array}{c}\text { Hard grey crust, below } \\
\text { yellow crust }\end{array}$ & & & & & & & & & $?$ & $\bullet$ & & & & & & & \\
\hline Cham $5 \mathrm{~N}$ & $\begin{array}{c}\text { Phosphate flowstone } \\
\text { in wall niche }\end{array}$ & & $\mathrm{x}$ & & & $?$ & & & $\bullet$ & $\bullet$ & & & & & & & & \\
\hline Cham 6N & $\begin{array}{l}\text { Soft grey deposit along } \\
\text { wall }\end{array}$ & & $\mathrm{x}$ & & & & & & $\mathrm{x}$ & & & $\bullet$ & & $\bullet$ & & & & \\
\hline Cham $7 \mathrm{~N}$ & Rock pillar hat & & & & & & & & & $\mathrm{x}$ & & $\mathrm{x}$ & & & & & & \\
\hline Cham 8N & $\begin{array}{l}\text { Yellow soft crust on } \\
\text { fresh guano }\end{array}$ & & $\bullet$ & & ? & & & & & & & & & & & & & \\
\hline Cham 10N & $\begin{array}{c}\text { White crust on red } \\
\text { clay }\end{array}$ & & $\bullet$ & & & & & & $\mathrm{x}$ & $\mathrm{x}$ & & & & $\bullet$ & & & & \\
\hline BalD 1 & $\begin{array}{l}\text { Intermediate Unit - } \\
\text { light weathered clay }\end{array}$ & & $\mathrm{x}$ & & & $?$ & & & & $\mathrm{x}$ & & $\mathrm{x}$ & & & & & & \\
\hline BalD 2a & $\begin{array}{l}\text { Up. Unit - brown } \\
\text { crust, on BalD 2b }\end{array}$ & & & & & & & & & $\mathrm{x}$ & & $\bullet$ & & & & & & \\
\hline BalD 2b & $\begin{array}{l}\text { Intermediate Unit - } \\
\text { light weathered clay }\end{array}$ & & & & & & & & & $\mathrm{x}$ & & $\mathrm{x}$ & & & & & & \\
\hline BalD 3a & $\begin{array}{l}\text { Interm. Unit -black } \\
\text { seam around carb. } \\
\text { block }\end{array}$ & $\mathrm{x}$ & $\mathrm{x}$ & & & & & $\bullet$ & & & & & $\mathrm{x}$ & & & & & ? \\
\hline BalD 3b & $\begin{array}{l}\text { Interm. Unit - lighter } \\
\text { aureole around BalD } \\
\text { 3a }\end{array}$ & $\mathrm{x}$ & $\mathrm{x}$ & & & $?$ & & $\mathrm{x}$ & $\mathrm{x}$ & & & & $?$ & & & & & $\mathrm{x}$ \\
\hline BalD 4 & $\begin{array}{l}\text { Up. Unit - purple } \\
\text { crust on grey } \\
\text { phosphates }\end{array}$ & & $\mathrm{x}$ & & & & & & $\mathrm{x}$ & $\bullet$ & & $\mathrm{x}$ & & & & & & \\
\hline BalD 5 & $\begin{array}{l}\text { Upper Unit - top of } \\
\text { grey phosphates }\end{array}$ & & & & & & & & $\bullet$ & $\mathrm{x}$ & & & & & & & & \\
\hline BalD 6 & $\begin{array}{l}\text { Upper Unit - hard } \\
\text { brown crust on top }\end{array}$ & & & & $?$ & & & & $\mathrm{x}$ & & $\mathrm{x}$ & $\bullet$ & & & & & & \\
\hline Cham 16T & $\begin{array}{l}\text { Light grey block on } \\
\text { top }\end{array}$ & & & & & & & & & $?$ & $\bullet$ & & & & $\mathrm{x}$ & & & \\
\hline BalU 1 & $\begin{array}{c}\text { Fine sand (-1 m / } \\
\text { surf.) }\end{array}$ & & & & & & & & & & & $\bullet$ & & & & & & \\
\hline BalU 2 & $\begin{array}{c}\text { Black layer in BalU } 1 \\
(-3 \mathrm{~m} / \text { surf. })\end{array}$ & & $\mathrm{x}$ & & & $?$ & $\bullet$ & & $\mathrm{x}$ & & & $\mathrm{x}$ & $\bullet$ & & & & & \\
\hline BalU 3a & $\begin{array}{l}\text { Crust / contact } \\
\text { carbonate rock }\end{array}$ & & & & & & $\bullet$ & & $\bullet$ & & & & & & & & & \\
\hline BalU 3b & Below BalU 3a & & & & & & $\bullet$ & & & $\mathrm{x}$ & & $?$ & & & & & & \\
\hline
\end{tabular}

*even if not recognized as mineral species by IMA, this intermediate form between strengite and variscite is present in many samples

grey layer (Cham $4 \mathrm{~N})$ is mainly strengite with some Al-rich strengite, mixed with detrital material (illite or muscovite). The upper yellow layer (Cham $3 \mathrm{~N}$ ) consists of variscite and gypsum, with possibly strengite and ardealite, and quartz (Fig. $5 \mathrm{C}$ ). Cham $5 \mathrm{~N}$ is composed of variscite and Al-rich strengite, some gypsum or brushite, along with detrital quartz (Fig. 5D). Cham 7N is composed of Fe phosphates, Al-rich strengite and leucophosphite, with quartz and muscovite/illite (Fig. 5E). The pale whitish-yellowish lumpy minerals (Cham $8 \mathrm{~N}$ ) were identified as gypsum and possibly ardealite, with some quartz (Fig. 5F-G). The thin white crust (Cham 10N) covering the red-brown clays is composed of Al-rich strengite, strengite, variscite, 
crandallite, gypsum, and quartz and muscovite/illite (Fig. 5H-I). The underlying red-brown clay deposits is of detrital origin (silicates, feldspar, clay).

\section{Balcony Gallery}

Balcony Gallery, downstream profile (BalD

- Fig. 7A). Under microscope, the grey material of the Intermediate Unit (BalD 1) is composed of crystals, mainly white angular grains, associated to some smoky transparent prisms, opaque green blocks, and dark platelets. XRD analysis reveals a majority of detrital elements of fluvial origin (quartz, muscovite, microcline), associated to phosphates (leucophosphite, Al-rich strengite, strengite), and gypsum (or brushite) (Fig. 7B). Between BALD 1 and Upper Unit $C$, the darker upper part of the crust (BalD 2a) has a very similar composition to the grey material (quartz, muscovite, leucophosphite/ spheniscidite, and Al-rich strengite). The lower light part of the crust (BalD 2b) of the same grey material has a similar mineral assemblage as BalD 2a. Under microscope, the weathered peel (BalD $3 \mathrm{~b}$ ) and the thin black layer (BalD 3a) at the contact of the intact block show aggregates of white crystal, infiltrated by black material, more abundant in the thin black layer. This black material is made of piles of prismatic crystals grading from transparent to light to darker orange and has a bituminous aspect. The light weathered material (BalD 3b) is mainly composed of fluvial detrital minerals (quartz, muscovite, feldspar), kaolinite, gypsum (or brushite), phosphates (variscite, fluorapatite, minyulite), and birnessite. Mineralogically, the thin black layer (BalD 3a) is quite similar to BalD 3b, however with only fluorapatite as phosphate.

The Upper Unit, BalD 5 (Fig. 7C) is made exclusively of micron-size white crystals, mainly composed of quartz and variscite, and some intermediates minerals with various content of $\mathrm{Fe}$ and $\mathrm{Al}$ between strengite and variscite, such as the Al-rich strengite. The pink crust (BalD 4, Fig. 7D) shows under microscope a pink crystalline crust grading to the underlying grey phosphate, however, with exactly the same texture, but different color. It is mainly composed of quartz and Al-rich strengite, associated to variscite, leucophosphite/spheniscidite, and possibly illite-group minerals. On top, the brown crust (BalD 6) consists of quartz and muscovite, associated with leucophosphite/spheniscidite, strengite, variscite, and possibly ardealite.

To sum up, the downstream profile of Balcony Gallery mainly consist of resistant detrital minerals of fluvial origin and Al-Fe phosphates packing large blocks of the host rock, some being deeply weathered and covered by thin apatite and Mn-rich crust.

Balcony Gallery, upstream profile (BalU - Fig. 8). The top of the Lower Unit crust (BalU 3a) is mainly composed of variscite, along with quartz, muscovite/ illite-group minerals, and hydroxylapatite. The underlying part of the crust (BalU $3 \mathrm{~b}$ ) at the contact with the carbonate bedrock, hydroxylapatite is the common phase along with leucophosphite/ spheniscidite, Al-rich strengite, and quartz, muscovite/illite. Quartz, leucophosphite, and muscovite, are the main minerals in the grey-white sandy material (BalU 1) of the Upper Unit (C). The thin black layer (BalU 2) is composed of hydroxylapatite, minyulite, leucophosphite/spheniscidite, Fe-rich variscite, gypsum (or brushite), quartz, feldspar, muscovite. Under microscope, it displays white to transparent crystals, with some millimetric transparent prismatic crystals, some being tinted in black. The block of hard grey vuggy material on top (Cham 16T) contains a mixture of quartz, strengite, phosphosiderite, and Al-rich strengite. To resume, the upstream Balcony profile is mainly composed of a thick homogenous deposit mixing fluvial quartz and Al-Fe phosphates.

\section{Radiometric dating of speleothems}

The detailed U-series dataset spanning the period 107 to $38 \mathrm{ka}$ is available in Supplementary, Table S1. Samples GC10-10A, GC10-10B, GC10-8A, Cham J, and Cham $\mathrm{E}$ have a low ${ }^{230} \mathrm{Th} /{ }^{232} \mathrm{Th}(<120)$, that indicates detrital contamination. Thus, their ages cannot be used for precise chronology. Chameav A1 and A2, which age can be considered as reliable, have two ages at $97.6 \pm 0.6$ and $107 \pm 1 \mathrm{ka}$, for the same flowstone from the upstream part of the River Gallery. The stalagmites fossilizing the debris talus at the downstream end of Amelineau Gallery, GC10-10A, $10 \mathrm{~B}, 8 \mathrm{~B}$, and $8 \mathrm{~A}$, provided ages between 65 and $50 \mathrm{ka}$. Only $8 \mathrm{~B}$ at $50.1 \pm 4.4$ can be considered as relatively reliable, however all ages are grouped in a rather narrow period indicating their consistence. Cham $\mathrm{J}$ and Cham E, corresponding to corroded stalagmites covered by old phosphates and guano in upstream part of River Gallery, returned ages from 42 to $38 \mathrm{ka}$.

\section{DISCUSSION}

\section{Mineralogenesis}

Composition of guano depends on the bat's diet, which in this region is exclusively insectivorous. Guano deposits are mainly made of insect chitin accumulations, together with other minor organic compounds. The composition of guano includes the usual organic elements: C-H-O-N, with $\mathrm{P}, \mathrm{S}$, and secondary $\mathrm{K}, \mathrm{Na}, \mathrm{Cl}, \mathrm{Ca}, \mathrm{Mg}, \mathrm{Fe}, \mathrm{Al}$, and $\mathrm{Si}$ (Martini \& Kavalieris, 1978; Wurster et al., 2015; Misra et al., 2019). The decay of organic matter results in gaseous volatilization, leaching of most soluble compounds, and precipitation of phosphates (Frazier et al., 1963). Volatilization mainly releases carbon dioxide $\left[\mathrm{CO}_{2}\right]$, ammonia $\left[\mathrm{NH}_{3}\right]$, and nitrogen $\left[\mathrm{N}_{2}\right]$. Various acids are produced both above in the air or inside the guano pile, and are at the origin of the conspicuous corrosion in the surrounding of guano. These are sulfuric acid $\left[\mathrm{H}_{2} \mathrm{SO}_{4}\right]$, nitric acid $\left[\mathrm{HNO}_{3}\right]$, and carbonic acid $\left[\mathrm{H}_{2} \mathrm{CO}_{3}\right]$; phosphoric acid $\left[\mathrm{H}_{3} \mathrm{PO}_{4}\right]$ is restricted to the guano pile (Audra et al., 2016). The common ions presents in guano are ammonium $\left[\mathrm{NH}_{4}{ }^{+}\right]$, nitrate $\left[\mathrm{NO}_{3}{ }^{-}\right]$, phosphate $\left[\mathrm{PO}_{4}{ }^{3-}\right]$, sulfate $\left[\mathrm{SO}_{4}{ }^{2-}\right]$, and potassium $\left[\mathrm{K}^{+}\right]$, along with magnesium $\left[\mathrm{Mg}^{2+}\right]$ and calcium $\left[\mathrm{Ca}^{2+}\right]$ mainly provided by dripping of solutes originated 
from solution of the bedrock. In damp environments, $\mathrm{NH}_{4}{ }^{+}, \mathrm{NO}_{3}{ }^{-}, \mathrm{SO}_{4}{ }^{2-}, \mathrm{Mg}^{2+}, \mathrm{Ca}^{2+}$, and $\mathrm{K}^{+}$, are easily leached away. In dry environments, evaporation leads to precipitation as various minerals (nitrates, sulfates, carbonates), as crusts and fibers upon and around the guano piles. Less mobile phosphate ion reacts within its environment and concentrates as phosphate minerals. They combine with the abovementioned ions in solution, and allogenic ions $\left(\mathrm{Al}^{3+}\right.$, $\mathrm{Fe}^{3+}, \mathrm{K}^{+}, \mathrm{Mn}^{2+}$ ) provided by detrital material brought as dust, wall weathering or sediment accumulation on the ground, and also from bones and teeth remnants $\left(\mathrm{F}^{-}\right)$. The variety of combinations generating numerous phosphate minerals strongly depends on the environmental conditions related to the degree of guano decay and to microclimatic conditions, mainly moisture/evaporation intensity and drainage efficiency (Onac, 2019).

\section{Three categories of guano minerals}

Hereafter, we describe the identified minerals into three categories, corresponding to (i) precursors that first appear when guano starts decaying, (ii) those precipitating at the contact of guano and carbonates bedrock or speleothems, and (iii) those forming after reactions with non-carbonate materials such as clay and fluvial sediments. Processes and minerals are illustrated in Figure 9.

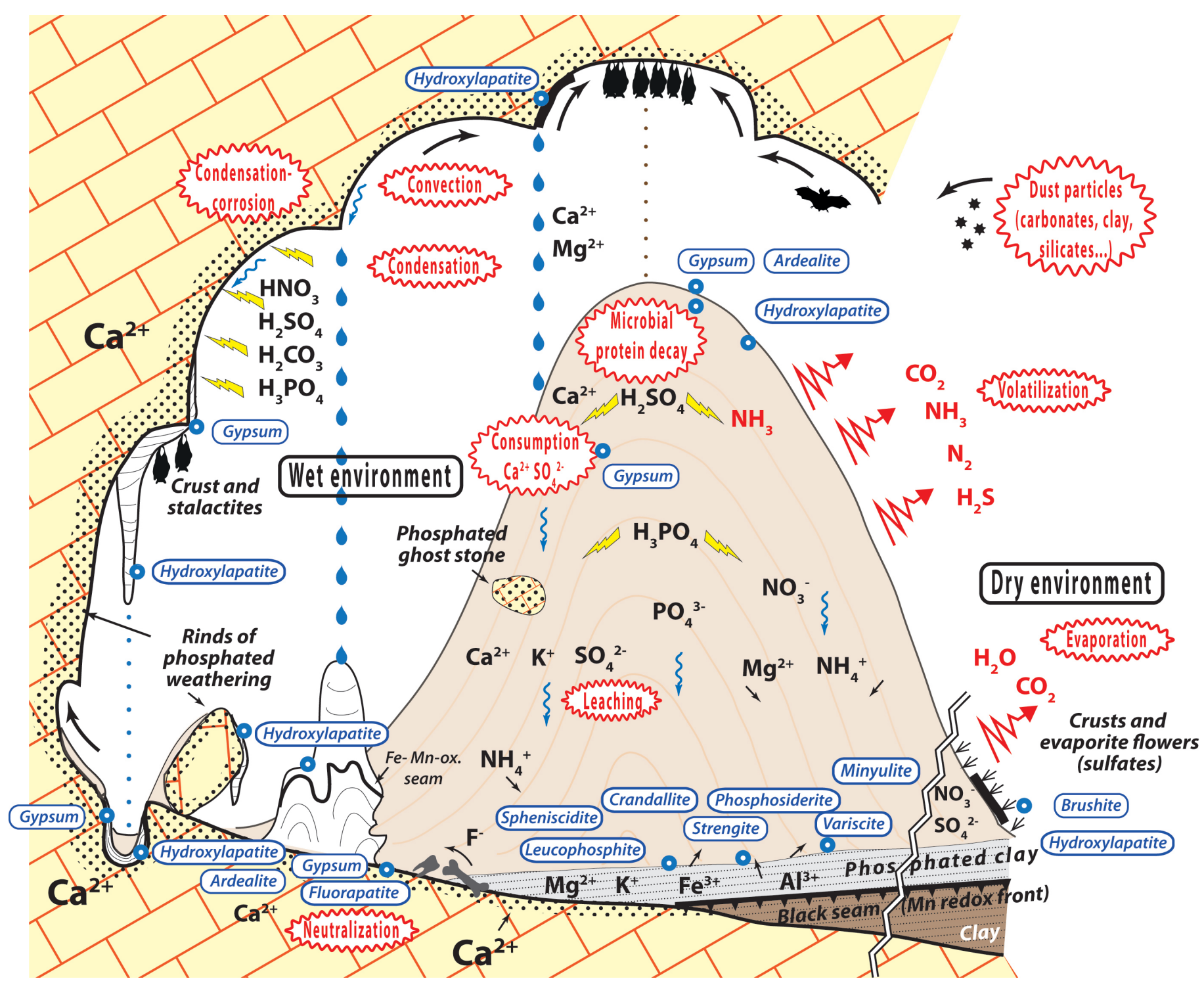

Fig. 9. Synthesis of guano-related minerals formation (after Audra et al., 2019, adapted to the studied site). See text for details.

\section{Precursors of guano mineralization}

Guano decay releases sulfates among the first by-products, which are eventually leached away. Phosphates are much less mobile and thus gradually concentrate. We identified in Chameau Cave a common sulfate mineral, gypsum; a phosphatesulfate, ardealite; and one phosphate, brushite. In the gypsum-brushite isodimorph system, ardealite is the intermediate member. Consequently, exchanges can easily occur according to the activity of ions present, giving rise to a given mineral, or more generally to various combinations of minerals. These minerals develop on the surface of fresh guano as lumpy yellowish aggregates made of both gypsumardealite (Cham3a, Cham 3N) or as pure gypsum (Cham 4). Gypsum and brushite are also present inside more evolved material, at the contact between weathered limestone blocks and phosphate deposits (BaldD 1, BalD 3a, BalD 3b). These Ca sulfate / phosphate-sulfate / phosphate minerals derive from the interaction of guano-sourced acidic solutions with $\mathrm{Ca}^{2+}$ in limestone bedrock, speleothems, or drip 
water. Those minerals are resistant in the very acidic conditions occurring in decaying guano, especially for gypsum and ardealite, less for brushite. Humidity is required for the mineralization process; however, rather dry (evaporation) or poorly drained conditions are needed for the development and conservation of gypsum and ardealite, with the latter one requiring a damp environment (Hill \& Forti, 1997; Audra et al., 2019). For Cham $8 \mathrm{~N}$, no trace of dripping is visible on the guano pile. $\mathrm{Ca}^{2+}$ might originate from the dissolution of carbonate floor by aggressive guano, with solutes migrating upward by capillarity driven by the dry outer environment. For Cham 4, moisture from dripping is present in the vicinity, which migrates laterally toward the outer drier area by capillarity (Fig. 4F).

All samples with these precursor minerals also contain quartz or other detrital minerals. At least for a fresh guano surface, these detrital minerals cannot come from a mixing with underlying fluvial deposits, thus dust contamination is likely in these cases. It could also account for the $\mathrm{Ca}^{2+}$ source when dripping is not present. In addition, another possible scenario is the upward migration of the solutes from the dissolved rock floor.

\section{Phosphates originating from reaction with carbonates}

The carbonates are present in host rock (calcite, dolomite) and speleothems (calcite). Apatite phosphate minerals occur often in caves, with hydroxylapatite and fluorapatite being the most common. They form by neutralization of the acid solutes at the contact of limestone or speleothems, which provide $\mathrm{Ca}^{2+}$. If animal bones or teeth are present, the active fluoride ion $\left(\mathrm{F}^{-}\right)$easily replaces hydroxyl ion $\left(\mathrm{OH}^{-}\right)$, making fluorapatite. Both minerals are stable above $\mathrm{pH} \sim 6$. Even if decaying guano produces a more acidic environment, such close-to-neutral conditions are easily met at the contact of carbonate rock or speleothems that immediately neutralize the acidic solutions. Their occurrence in our analyzed samples is not frequent, because we avoided sampling evident sites like brown apatite crust on walls, which however are very frequent.

\section{Phosphates originating from reaction with phyllosilicates}

Phyllosilicates are present in detrital clay produced by the weathering of marly bedding parting and in fluvial deposits brought into the cave by past underground flow (Audra et al., 2016, 2019). Guano decay produces very acidic conditions allowing hydrolysis of fragile phyllosilicates, which release cations $\left(\mathrm{Al}^{3+}, \mathrm{Fe}^{3+}\right.$, and $\left.\mathrm{K}^{+}\right)$. Pyrite oxidation from shale partings may also provide $\mathrm{Fe}^{3+}$, and guano decay in turn provides $\mathrm{NH}_{4}{ }^{+}$and also $\mathrm{K}^{+}$. All these species may combine with the $\mathrm{PO}_{4}{ }^{3-}$. The most common minerals are variscite and strengite, which incorporate $\mathrm{Al}$ and $\mathrm{Fe}$, respectively. These minerals are characterized by the highest $\mathrm{Fe} / \mathrm{P}$ and $\mathrm{Al} / \mathrm{P}$ ratios and are only soluble in extremely acidic conditions, hence their stability in a cave environment. As a consequence, they constitute the most extensive deposits, as end-members of the most evolved minerals. Their isostructural properties allow exchanging $\mathrm{Al}$ and $\mathrm{Fe}$, depending on their respective activity. Various intermediate species may appear between both end-members of the strengitevariscite series: in presence of clay, Al activity increases and may substitute for $\mathrm{Fe}^{3+}$ of strengite, making Al-rich strengite (Supplementary Fig. S2), and similarly for $\mathrm{Fe}$ on variscite producing Fe-rich variscite. Note that both intermediate minerals are not recognized by IMA/CNMNC. Phosphosiderite, a dimorph of strengite, was found (Supplementary Fig. S3). Leucophosphite, and spheniscidite the $\mathrm{NH}_{4}$-dominant analogue of leucophosphite, are found on top of stable Fe-phosphate deposits, generally as hard crust. Solute migration toward the dry surface where evaporation occurs seems to play an important role. Clay must be absent, otherwise the strongest activity of $\mathrm{Al}$ would replace $\mathrm{Fe}$ (Flicoteau \& Lucas, 1984). The incorporation of $\mathrm{K}^{+}$and $\mathrm{NH}_{4}^{+}$into a hard crust on the guano surface is related to the vicinity of fresh guano, which when it decays provides acid and the corresponding ions, and also probably to some wet/dry cycles favoring precipitation and hardening (Tiessen et al., 1996). Thereafter, these minerals, which are only soluble in acids, could remain stable (Wilson \& Bain, 1986). Crandallite is also found on the guano surface, often associated with leucophosphite or spheniscidite (Supplementary Fig. S5). $\mathrm{Ca}^{2+}$ could come from discrete dripping or from carbonate rock particles close to recent guano, which in turn produces the required acidity. The sample Cham $6 \mathrm{~N}$ is located at the foot of a weathered marly wall where grey clay particles are piling, at the origin of $\mathrm{Al}$ and probably also of Ca. Minyulite was known before only for an occurrence in Boons Cave, South Africa (Martini \& Kavalieris, 1978). It derives from the reaction of guano on a clay substratum. In Chameau Cave, it is associated with deeply weathered material: with fluvial material containing kaolinite (BalD 3b), or in a black layer accumulation (BalU 2), sandwiched in between phosphatized fluvial material (Supplementary Fig. S1).

\section{Minerals other than phosphates (silicates, sulfates, oxides, and hydroxides) \\ Silicates, such as micas and feldspars are} abundant in fluvial material. Among micas, only muscovite was identified. Regarding feldspars, only the most resistant were detected, namely K-feldspars (orthose, microcline) and Na-plagioclases (albite). For clay minerals, kaolinite appeared in deeply weathered material such as bleached layer in guano pots (Cham 9b) and black seams associated with Fe-Mn oxyhydroxides (Cham 6, BalD 3a, BalD 3b). All of these resistant minerals are witnesses of the intense weathering of the initial fluvial material due to the aggressive conditions provided by guano decay, sometimes possibly reworked as dust. Beyond a fluvial origin, another source of clay could be the weathering of marly walls through condensation-corrosion, which removes carbonates as solutes and releases the insoluble part. This corrosion is particularly evident in Nadia Gallery (Cham 3-4-5-6-7N samples), where A1- 
and Fe-phosphates can be interpreted as the result of interaction between guano, clay and Fe-oxides from wall weathering, combined with indirect contribution of fluvial or surface material through dust and runoff.

For sulfates, in addition to gypsum discussed above, we only found one occurrence of baryte, which is usually of hydrothermal origin. It was found in a black seam between calcite layers, associated to detrital material, fluorapatite, and Fe oxyhydroxides. This particular black seam clearly corresponds to a condensation layer at the contact between phosphates and calcite; however, the origin of this only occurrence of baryte remains uncertain.

Oxides and hydroxides of $\mathrm{Fe}$ and $\mathrm{Mn}$ are not that frequent, and are also limited to some samples in black seams. They are represented by goethite, hematite, and birnessite. They precipitate when acidic guano leachates are neutralized onto carbonate substratum, and are at the origin of the color of the black or brown seams. Quartz is also frequently associated with most of the identified phosphates. An authigenic origin can be excluded, since such minerals are not present in the local host rock, at least not in sufficient quantities. However, some quartz conglomerate layers, present in the lower part of the carbonate succession but exposed upstream at higher altitude, could also represent a potential source.

\section{Balcony Gallery: the "digestion" of old fluvial sediments through guano decay}

In Balcony Gallery, in addition to rare collapsed blocks, the floor is covered by loose sediments, mainly phosphate and fresh or old guano. Thanks to the natural profiles cutting each end, its thickness can be assessed as being between 5 to $8 \mathrm{~m}$. Similar accumulations might be present in any fossil gallery, which however are not visible, buried under the surface deposits considerably reworked from tourist trails. In the River Gallery, frequent flooding has swept away most of the loose material; however, some veneers of hardened crust are visible, and are probably made of strengite or variscite. In the Lower Unit of the Balcony Gallery, even if the occurrence contains phosphates, the sediments still display the original fluvial structure and materials, made of clay, sands, and huge collapsed blocks. However, the Upper Unit is made of a 2-3 m-thick, homogenous, grey, hard and porous phosphates, principally strengite and variscite, associated with quartz (Supplementary Fig. S4). Conditions to reach such deeply-weathered material requires a continuous renewal of the strong acidic source provided by guano decay. The leaching of other ions ending to variscite would require $4<\mathrm{pH}<6$, beyond which $\mathrm{Al}^{3+}$ is leached, and $2.5<\mathrm{pH}<6$ for strengite beyond which $\mathrm{Fe}^{3+}$ is in turn leached, resulting in almost pure quartz material (Martini \& Kavalieris, 1978). However, such quartzrich end-member of weathering was not reached in Chameau Cave. According to the dimensions of the Balcony Gallery ( $\mathrm{L}=60 \mathrm{~m}$; width $=15 \mathrm{~m})$, the phosphatic material of the Upper Unit corresponds to a residual volume of about $3,000 \mathrm{~m}^{3}$ resulting from the "digestion" of fluvial deposits by decaying guano.
The genesis of gypsum "candy-floss" accumulations

The gold-like, candy-floss-like gypsum cone (Cham 2N, Fig. 5A) is an exceptional deposit because of its size, purity, and rare occurrence. Its genesis remains questionable. Martini \& Kavalieris (1978) suggested a complete breakdown of guano into pure gypsum in damp and acidic conditions. Another possible origin could be related to the accumulation of gypsum particles that crystallize on the ceiling from the evaporation of sulfate solutions that detach and fall by gravity as they form. Our opinion favors the second scenario, since an in-situ diagenesis would probably have preserved some guano particles and the deposit structure, which apparently is not the case. Since such type of formation is exceptional and mentioned in only few sites on the planet (Martini \& Kavalieris, 1978), we did not yet investigate it directly in order to keep it intact for conservation.

\section{Environmental conditions}

The control of environmental conditions is a complex topic. The assessment of the role of different parameters in various combinations has been highlighted in only a few studies (e.g., Onac \& Veres, 2003; Shahack-Gross et al., 2004; Onac et al., 2005; Giurgiu \& Tămaş, 2013; Audra et al., 2019). However, a better understanding would require more studies that are beyond the scope of this paper. It mainly involves physical parameters, such as relative humidity (HR) and acidity $(\mathrm{pH})$ associated to the activity of various ionic species. The temperature indirectly influences relative humidity, since it causes condensation or evaporation by the moving air masses that alternatively warms or cools, thus bringing moisture or dryness to the sediments and guano deposits. Strong dry air flow is also responsible of the transport of allogenic components involved in phosphate generation, such as dust particles in the dry air.

We must emphasize that the current microclimatic conditions in the cave, as described by our first investigations, probably do not correspond to those from the past, which could have been significantly different both in terms of temperature and humidity. Considerations of the recent environmental parameters are valid only for active or recent guano deposits and for the precursor minerals. We cannot made conclusions about the role of microclimate for phosphates deriving from fluvial sediments diagenesis, which are obviously old.

\section{Acidity}

Fresh guano decay creates an acidic environment. Hydroxylapatite and fluorapatite are stable above or at neutral $\mathrm{pH}(>6.2-6.8)$ following neutralization of acidity at the contact with the carbonate host-rock. Brushite is stable in near neutral environments $(\mathrm{pH}>6)$, whereas gypsum and ardealite can remain stable in more acidic environment $(\mathrm{pH}>4-5)$. Feand Al-phosphates are stable in even more acidic environments: variscite $(\mathrm{pH}>4)$ and $\mathrm{pH}>2.5$ for strengite (Martini \& Kavalieris, 1978). However, their stability field extends on a wide range up to above neutrality following the entire consumption of acidic 
potential and leaching of other species after complete guano mineralization.

\section{Moisture and dryness}

Humidity is required for guano mineralization. In arid areas with permanently dry conditions, guano can remain for ages as dry pellets with extremely slow and very limited mineralization, as in Slaughter Canyon Cave in the Chihuahua Desert, New Mexico, where it is older than 400 ka (Polyak et al., 2006). In such environments, even bat urea evaporates to form organic and nitrate minerals (Martini \& Kavalieris, 1978; Audra et al., 2017). When moisture is available and draining is active, leaching of sulfates occurs, causing gypsum and ardealite to disappear, while leaving only brushite. Persistence of gypsum requires a subtle balance between moisture and evaporation, which is found in transition areas between zones of discrete dripping and dry areas. Dripping provides the required moisture for guano decay, making sulfate solutions. Then capillarity attracts moisture outwards toward the drier areas where gypsum can form after evaporation. In fact, moisture amount is probably significant in the whole of guano deposits, including areas dry in surface, allowing for the slow breakdown of guano and the growth of gypsum only on dry surfaces. Rings of gypsum aggregates that follow moisture zones clearly show such conditions (Fig. 4F). Leucophosphite/spheniscidite crystallization also requires similar conditions, with at least the temporary presence of moisture in guano and dryness at the contact of rock that allow the precipitation of crusts. Their solubility in acidic conditions requires in addition the absence of wet decaying guano in the vicinity.

Regarding the gypsum "candy-floss", if considering an origin from solid particles formed on the ceiling and falling on the floor, it would require condensation humidity on top of the cupola where bats are roosting, which is expected (Lundberg \& McFarlane, 2009, 2012, 2015; Audra et al., 2016). Then evaporation of the film of sulfate solutions at the lower edge of the cupola allows crystallization of gypsum particles that gradually detach and fall on the floor, where their conservation is possible due to drier conditions, which is also expected. In fact, the specificity of the conditions allowing candy-floss development would essentially be the presence of evaporation even in the lowermost parts of the ceiling at the cupolas edges. Such a hypothesis must be tested: it requires a larger extension of dry areas including part of the ceiling, whereas the top of the cupola must remain wet.

\section{Dust and solid aerosols}

Beyond phosphates originating from direct interaction between fluvial sediments and decaying guano, some samples located on the surface of thick guano piles (e.g., Cham 3) probably cannot be explained in that way. Indeed, in Chameau Cave dry conditions occur in most places except in the ceiling of the inner galleries that are moisturized by condensation. Air flow is also present, with strong circulation in the passages between both entrances, and significant velocities in the convection loops of the inner passages. Under those conditions, dust and solid aerosols are easily transported anywhere. Fine particles of carbonates, quartz, and clay can be reworked from their original position, especially from the floor, where they mix after redeposition with ongoing decaying fresh guano. Such dust transport is particularly active in dry caves and especially in show caves where large number of visitors are walking (Michie, 2001, and references therein). Even if the individual particles are in the micron size range or less, the cumulate deposition of dust after years can reach kilograms.

\section{The age of guano-related minerals}

No direct radiometric dating of the guano and guano-related minerals are available for Chameau Cave. For the latter, even if uranium can be trapped in phosphate minerals, its lattice do not offer close system conditions, thus post-crystallization exchanges may strongly affect the geochemical results and their age (Bahain, pers. comm.). Nevertheless, some indirect clues can be deduced from U/Th ages obtained on calcite speleothems: (i) the four ages from stalagmites covering the final plug of Amélineau Gallery ranging between 65 and $50 \mathrm{ka}$ indicate that the gallery was certainly closed and abandoned at that time; (ii) the two ages of 107 and $98 \mathrm{ka}$ from the corroded flowstone in the upstream part of River Gallery show that this lower level was already in vadose conditions at that time; (iii) the two corroded flowstones covered by old phosphates and guano in upstream part of River Gallery returned ages from 42 to $38 \mathrm{ka}$. Although these last ages are not reliable, they tend to indicate a period of calcite deposition around $40 \mathrm{ka}$, followed by intense guano deposition. These ages show that the most conspicuous deposits of phosphates are probably younger than $40 \mathrm{ka}$. Some likely formed at least from around $100 \mathrm{ka}$ since the cave passages - at least those now abandoned were already present in their current morphology. And guano-related minerals still form in the active guano deposits. It is highly probable that some past climatic periods offered various favorable conditions for large bat colonies, resulting in successive large guano accumulations and phosphate diagenesis. This detailed chronological issue still remains open.

\section{CONCLUSION}

In this paper, we shown the high mineralogical diversity of Chameau Cave in Eastern Morocco, which mainly results from guano-related acids reacting with allogenic fluvial deposits. We identified 12 guano-related minerals, mainly phosphates, assigned to three categories: (i) the precursors present in fresh decaying guano, with one sulfate (gypsum), one phosphate-sulfate (ardealite), and one phosphate (brushite); (ii) two common phosphates (hydroxylapatite, fluorapatite) resulting from neutralization at the contact of carbonate bedrock; (iii) nine phosphates (variscite, strengite, Al-rich strengite, Fe-rich variscite, phosphosiderite, leucophosphite, spheniscidite, crandallite, and minyulite), resulting 
from the reactions with phyllosilicates. Variscite and strengite are the stable end-members of Al- and $\mathrm{Fe}$-phosphates, respectively. Due to easy $\mathrm{Fe}$ and $\mathrm{Al}$ exchange between the latter, Al-strengite and Fevariscite are intermediate varieties, not recognized as true minerals in the IMA-CNMNC list. Spheniscidite and minyulite are rare cave minerals, each known in only a couple of occurrences. This last category includes minerals formed from the reaction between acidic guano leachates and allogenic fluvial minerals, where only the most resistant detrital minerals have been preserved (quartz, muscovite, K-feldspars), associated to secondary kaolinite. For the phosphates, strengite and variscite are the most abundant. Feand $\mathrm{Mn}$ - oxyhydroxides concentrate as black seams at the contact between weathered fluvial sediments and carbonate bedrock or fragments.

The pure candy-floss gypsum pile is a rare type of deposit, which requires specific dry conditions, with condensation runoff on top of cupolas as the source of sulfates. We suggest this gypsum pile formed by the detachment of gypsum particles precipitated by evaporation at the edge of cupolas that gradually piled up by accumulating on the floor as pure gypsumparticle cones.

Environmental conditions (especially $\mathrm{pH}$ and relative moisture) are very important to determine the occurrence of a given mineral or a group of minerals. Many minerals require both humidity for guano to decay and dry conditions for their precipitation (leucophosphite, etc.). Such conditions can be met either during seasonal dry/wet cycles, or more frequently in the presence of discrete damp areas resulting from condensation in the upper part of high cupolas in a generally very dry environment. In addition, dust appears to be an essential source to explain the presence of some species (carbonates, clay, quartz) in association or in the composition of some phosphate minerals.

Finally, the Chameau Cave appears as an outstanding site for bat guano-related cave minerals, especially phosphates. More detailed studies would certainly provide more mineral identifications and additional insights for their genesis understanding. In addition, the amount of phosphate deposits indirectly emphasizes the major role of guano mineralization as a booster for cave evolution, by intense phosphatization of allogenic fluvial deposits and by condensationcorrosion at the origin of passage expansion in late stage, which is considerable in this and other caves harboring large guano deposits.

\section{ACKNOWLEDGEMENTS}

This study was granted by the Fondation de la Vallée de Zegzel. Pavel Bosák was supported by the Institutional financing of the Inst. Geol., Czech Acad. Sci. no. RVO6798531. We particularly thank Christian Dodelin, "Bat delegate" of the French Federation of Speleology (FFS), for identification of the bat species; Jean-Jacques Bahain, Yann Callot, and Jacques Martini for fruitful discussions; Daniel Borschneck for XRD analyses of samples Cham 3 to
$9 \mathrm{~b}$ at CEREGE; Roger Notonier for MEB images and EDX analyses at PRATIM; Olivier Grauby for the SEMTEM analysis at CINaM, all three at Aix Marseille University; Daniel Chailloux for participating at the survey of Chameau Cave; Hubert Camus for providing Morocco's cave inventory. The inhabitants of Zegzel village are especially acknowledged for their warm welcome during each field session. Finally, we are grateful to an anonymous reviewer, Carol A. Hill, Paolo Forti, and Bogdan P. Onac, for their insightful comments and suggestions.

Authorship statement: PA and LB designed and directed the study, and wrote the paper; $\mathrm{VH}$ performed the XRD analyses and interpretation; MEKB founded and supervised the study; SJ participated to field work and speleothems sampling for U/Th dating in the frame of A. Tayebi PhD; MR participated to field work, cave survey, and documentation. EPB, PB, $\mathrm{HC}$, and RLE performed the U/Th dating. All authors contributed to the writing and discussion of the manuscript.

\section{REFERENCES}

AEFCS, 1996. Plan Directeur des Aires protégées du Maroc. Unpublished Report. Administration des Eaux et Forêts et de la Conservation des Sols / BCEOM / SECA / ISR / EPHE, vol. 2, 3.

Audra, P., 2017. Hypogene caves in North Africa (Morocco, Algeria, Tunisia, Libya, Egypt). In: Klimchouk, A., Palmer, A.N., Audra, P., De Waele, J., Auler, A. (Eds.), Hypogene karst regions and caves of the world. Springer, New York, p. 853-864. https://doi.org/110.1007/978-3-319-53348-3 58

Audra, P., Barriquand, L., Bigot, J.Y., Cailhol, D., Caillaud, H., Vanara, N., Nobécourt, J.C., Madonia, G., Vattano, M., Renda, M., 2016. L'impact méconnu des chauvessouris et du guano dans l'évolution morphologique tardive des cavernes. Karstologia, 68, 1-20.

https://hal.archives-ouvertes.fr/hal-01838348/

Audra, P., Bosák P., Gázquez, F., Cailhol, D., Skála, R., Lenka, L., Jonášová, Š., Frumkin, A., Knez, M., Slabe, T., Zupan-Hajna, N., Al-Farraj Al-Kitbi, A., 2017. Bat urea minerals in arid environment. New cave mineral (Allantoin) from Kahf Kharrat Najem Cave, United Arab Emirates. International Journal of Speleology, 46(1), 81-92.

https://doi.org/10.5038/1827-806X.46.1.2001.

Audra, P., Heresanu, V., Barriquand, L., El Kadiri Boutchich M., 2018. Bat guano minerals (sulfates/ phosphates) in Chameau Show Cave (Morocco). 26 ${ }^{\text {th }}$ International Karst School "Milestones and Challenges in Karstology", Postojna, Karst research Institute (IZRK), Poster.

https://doi.org/10.13140/RG.2.2.23519.15523/1

Audra, P., De Waele, J., Bentaleb, I., Chroňáková, A., Krištůfek, V., D’Angeli, I.M., Carbone, C., Madonia, G., Vattano, M., Scopelliti, G., Cailhol, D., Vanara, N., Temovski, M., Bigot, J.Y., Nobécourt, J.C., Galli, E., Rull, F., Sanz-Arranz, A. 2019. Guano-related phosphates-rich minerals in European caves. International Journal of Speleology, 48(1), 75-105. https://doi.org/10.5038/1827-806X.48.1.2252.

Audra, P., Renda, M., Barriquand, L., Chailloux, D., E1 Kadiri Boutchich, M. 2021. Maroc, grotte du Chameau. Spéléo Magazine, 113, 20-27. 
Barriquand, L., Audra, P., El Kadiri Boutchich, M., 2018. Preliminary results on aerology and condensation in Chameau Cave, Zegzel Valley, Eastern Morocco. 26 ${ }^{\text {th }}$ International Karst School "Milestones and Challenges in Karstology", Postojna. Karst Research Institute (IZRK), Poster.

htps://doi.org/10.13140/RG.2.2.30230.04167

Boenlé, J., 1982. Maroc 82. Compte-rendu expé, Aragnado (Bull. du groupe spéléologique saltésien), $\mathrm{n}^{\circ}$ spécial, Sault.

Boenlé, J., 1983. Maroc 82. Expédition de reconnaissance organisée par le groupe de l'Aragnado. InfoPlongée, 37, 11. https://fr.calameo.com/read/0005346813818589 $\underline{27386}$

Brosset, A., 1960. Les mammifères du Maroc oriental, leur répartition, leur statut actuel. Bulletin de la Société des Sciences naturelles et physiques du Maroc, 40(3), 243-263.

Cailhol, D., Audra, P., Nehme, C., Nader, F.H., Garašić, M., Heresanu, V., Gucel, S., Charalambidou, I., Satterfield, L., Cheng, H., Edward, R.L., 2019. The contribution of condensation-corrosion in the morphological evolution of caves in semi-arid regions: preliminary investigations in the Kyrenia Range, Cyprus. Acta Carsologica, 48, 5-27. https://doi.org/10.3986/ac.v48i1.6782.

Camus, J., Lamouroux, C., 1981. Inventaire Spéléologique du Maroc. Direction de l'hydraulique, Ministère de l'équipement, Maroc, p. 205-206.

Cantet, J-P., 1976. Recherches spéléologiques dans le massif des Béni-Snassen, Maroc. Ouarnède (Bulletin du Groupe spéléologique des Pyrénées), 6, 15-21.

Cheng, H., Edwards, R.L., Shen, C.C., Polyak, V.J., Asmerom, Y., Woodhead, J., Hellstrom, J., Wang, Y., Kong, X., Spötl, C., Wang, X., Alexander Jr., E.C., 2013. Improvements in ${ }^{230} \mathrm{Th}$ dating, ${ }^{230} \mathrm{Th}$ and ${ }^{234} \mathrm{U}$ half-life values, and U-Th isotopic measurements by muAlti-collector inductively coupled plasma mass spectrometry. Earth and Planetary Science Letters, 371-372, 82-91.

https://doi.org/10.1016/j.eps1.2013.04.006

Dietz, C., von Helversen, O., Nill, D., 2007. L'encyclopédie des chauves-souris d'Europe et d'Afrique du Nord, Biologie, Caractéristiques, Protection. Delachaux et Niestlé, Paris, 400 p.

Dodelin, B., 2002. Identification des chiroptères de France à partir de restes osseux. Fédération Française de Spéléologie, Lyon, 48 p.

Flaquer Sanchez, C., Puig Montserrat, X., 2012. Els ratpenats de Catalunya. Brau Edicions, Figueras, 144 p.

Flicoteaux, R., Lucas, J., 1984. Weathering of phosphate minerals. In: Nriagu, J.O., Moore, P.B. (Eds.), Phosphate minerals. Springer, New York, p. 292-317.

Frazier, W.A., Lehr, J.R., Smith, J.P., 1963. The magnesium phosphates hannayite, schertelite and bobierrite. American Mineralogist, 48, 635-642. http:// www.minsocam.org/ammin/AM48/AM48 635.pdf

Ghazi, A., 1987. Étude géomorphologique et hydrologique du massif de Berkane, Maroc oriental. Thesis, Univ. Aix-Marseille 2, 2 vol.

Giurgiu, A., Tămaş, T., 2013. Mineralogical data on bat guano deposits from three Romanian caves. Studia UBB Geologia, 58(2), 13-18,

https://doi.org/10.5038/1937-8602.58.2.2

Gorka, P., Hercman, H., 2002. URANOTHOR v. 2.5. Delphi Code of calculation program and user guide. Unpublished report, Archive of Quaternary Geology Department, Institute of Geological Sciences, PAS, Warsaw.
Guyot, J.-L., 1984. Massif des Béni-Snassen (Maroc oriental), Grotte du Chameau. Bull. du GSBM, 11 (Maroc 83), 4-7. Groupe Spéléo Bagnols-Marcoule, Bagnols-sur-Cèze. https://www.gsbm.fr/publications / gsbm/1984_gsbm11/1984_GSBM11_04_Chameau.pdf

Hill, C.A., Forti, P., 1997. Cave minerals of the world (2nd ed.). National Speleological Society, Huntsville, Alabama, $464 \mathrm{p}$.

ICDP-PDF2 2020. Power Diffraction Database. https://www.icdd.com/pdf-2/

Joannis, R., 1915. Excursion aux grottes de Moulaï Ahmed ou du Zegzel. Bulletin de la Société de Géographie et d'Archéologie de la province d'Oran, XXXV, 278-284.

Lips, B., 1981. Écho des Vulcains, suppl. 41 (Maroc, bilan des explorations 79-81), 34-35, Lyon. https:// www.groupe-speleo-vulcain.com/echo_des_vulcains/ download.php?fichier=EV41\%20supl\%20Maroc.pdf

Lundberg, J., McFarlane, D.A., 2009. Bats and bell holes: the microclimatic impact of bat roosting, using a case study from Runaway Bay Caves, Jamaica. Geomorphology, 106, 78-85.

https://doi.org/10.1016/j.geomorph.2008.09.022

Lundberg, J., McFarlane, D.A., 2012. Post-speleogenetic biogenic modification of Gomantong Caves, Sabah, Borneo. Geomorphology, 157-158, 153-168. https://doi.org/10.1016/j.geomorph.2011.04.043

Lundberg, J., McFarlane, D.A., 2015. Microclimate and niche constructionism in tropical bat caves: A case study from Mount Elgon, Kenya. In: Feinberg, J., Gao, Y., Alexander, E.C. Jr. (Eds.), Caves and karst across time. Geological Society of America, 516, 19 p. https://doi.org/10.1130/2015.2516(17)

Martini, J., Kavalieris, I., 1978. Mineralogy of the Transvaal caves. South African Journal of Geology, 81(1), 47-54. https://journals.co.za/content/sajg/81/ $1 /$ AJA10120750 2836

Michie, N.A., 2001. An instrument and method for measurement of dust fall in caves, $14^{\text {th }}$ National Cave and Karst Management Symposium, Chattanooga, TN, 1999. Chattanooga, Southeastern Cave Conservancy, p. 123-128. http://nckms.org/wp-content/uploads/ 2018/05/michie.pdf

Misra, P.K., Gautam, N.K., Elangovan, V., 2019. Bat guano: a rich source of macro and microelements essential for plant growth. Annals of Plant and Soil Research, 21(1), 82-86, http://www.gkvsociety.com/ control/uploads/34560816.pdf

Onac, B.P., Vereş, D.Ş., 2003: Sequence of secondary phosphates deposition in a karst environment: evidence from Măgurici Cave (Romania). European Journal of Mineralogy, 15(4), 741-745.

https://doi.org/10.1127/0935-1221/2003/0015-0741

Onac, B.P., Forti, P., 2011 a. State of the art and challenges in cave minerals studies. Studia UBB Geologia, 56(1), 33-42. https://doi.org/10.5038/1937-8602.56.1.4

Onac, B.P., Forti, P., 2011 b. Minerogenetic mechanisms occurring in the cave environment: an overview. International Journal of Speleology, 40(2), 79-98. https://doi.org/10.5038/1827-806X.40.2.1

Onac B.P., Breban R., Kearns J., Tămaş T., 2002. Unusual minerals related to phosphate deposits in Cioclovina Cave, Şureanu Mts. (Romania). Theoretical and Applied Karstology, 15, 27-34.

Onac, B.P., Fornós, J.J., Ginés, A., Ginés, J., 2005. Mineralogical reconnaissance of caves from Mallorca Island. Endins, 27, 131-140. http://www.raco.cat/ index.php/Endins/article/view/122521/169644 
Onac, B.P., 2019. Minerals in caves. In: White, W.B., Culver, D.C., Pipan, T. (Eds.), Encyclopedia of caves. Academic Press, London, p. 699-709. https://doi.org/10.1016/B978-0-12-814124-3.00084-4

Polyak, V.J., Asmeron, Y., Rasmussen, J.B.T., 2006. Old bat guano in Slaughter Canyon Cave. In: Land, L., Lueth, V.W., Raatz, W., Boston, P., Love, D.W. (Eds.), Caves, karst of Southeastern New Mexico. New Mexico Geological Society, 57, 22-24.

https://nmgs.nmt.edu/publications/guidebooks/57/

Pons-Branchu, E., Douville, E., Roy-Barman, M., Dumont, E., Branchu, E., Thil, F., Frank, N., Bordier, L., Borst, W., 2014. A geochemical perspective on Parisian urban history based on U-Th dating, laminae counting and yttrium and REE concentrations of recent carbonates in underground aqueducts. Quaternary Geochronology, 24, 44-53. https://doi.org/10.1016/j.quageo.2014.08.001

Puşcaş, C.M., Kristaly, F., Stremțan, C.C., Onac, B.P., Effenberger, H.S., 2014. Stability of cave phosphates: Case study from Liliecilor Cave (Trascău Mountains, Romania). Neues Jahrbuch fur Mineralogie - Abhandlungen (Journal of Mineralogy and Geochemistry), 191(2), 157-168. https://doi.org/10.1127/0077-7757/2014/0254

Shahack-Gross, R., Berna, F., Karkanas, P., Weiner, S., 2004. Bat guano and preservation of archaeological remains in cave sites. Journal of Archaeological Science, 31, 1259-1272.

https://doi.org/10.1016/j.jas.2004.02.004

Tarrier, M., Delacre, J., 2007. Carnets de voyages naturalistes au Maroc. http://www.jdelacre.be/carnets/ index.html [accessed: March 2021]

Tayebi, A., 2011. Vulnérabilité des ressources en eau karstiques en milieu méditerranéen semi-aride : le massif des Beni Snassen (Maroc oriental). Approche pluridisciplinaire et utilisation des méthodes 'SIG'. Thesis, Grenoble University, 388 p., https://tel.archives-ouvertes.fr/tel-00710157

Tiessen, H., Lo Monaco, S., Ramirez, A. Santos, M.C.D., Shang, C., 1996. Phosphate minerals in a lateritic crust from Venezuela. Biogeochemistry, 34(1), 1-17. https://doi.org/10.1007/BF02182952

Wilson, M.J., Bain, D.C., 1986. Spheniscidite, a new phosphate mineral from Elephant Island, British Antarctic Territory. Mineralogical Magazine, 50, 291-293. https://doi.org/10.1180/minmag.1986.050.356.14

Wurster, C.M., Munksgaard, N., Zwart, C., Bird, M., 2015. The biogeochemistry of insectivorous cave guano: a case study from insular Southeast Asia. Biogeochemistry, 124, 163-175. https://doi.org/10.1007/s10533-015-0089-0 